\title{
Do the levels of industrial pollutants influence the distribution and abundance of dinoflagellate cysts in the recently-deposited sediment of a Mediterranean coastal ecosystem?
}

\author{
Habiba Zmerli Triki ${ }^{\mathrm{a}, *}$, Mohamed Laabir ${ }^{\mathrm{b}}$, Céline Lafabrie ${ }^{\mathrm{c}, \mathrm{d}}$, Dhafer Malouche ${ }^{\mathrm{e}}$, Chrystelle Bancon-Montigny ${ }^{\mathrm{f}}$, \\ Catherine Gonzalez ${ }^{g}$, Alan Deidun ${ }^{\mathrm{h}}$, Olivier Pringault ${ }^{\mathrm{c}, \mathrm{d}}$, Ons Kéfi Daly-Yahia ${ }^{\mathrm{a}}$ \\ a Institut Nationale Agronomique de Tunisie (INAT), IRESA - Université de Carthage, U.R Biologie Marine (FST El Manar I), 43 Avenue Charles Nicolle, 1082 Tunis, Tunisio \\ b Laboratoire Ecologie des Systèmes Marins Côtiers (ECOSYM), UMR 5119 UM2-CNRS-IRD-IFREMER-UM1, Université Montpellier, Place Eugène Bataillon, 34095 Montpellier, France \\ c UMR 9190 MARBEC IRD-Ifremer-CNRS-Université de Montpellier, Place Eugène Bataillon, Case 093, 34095 Montpellier Cedex 5, France \\ ' Faculté des Sciences de Bizerte, Université de Carthage, 7021 Zarzouna, Tunisia \\ e Ecole Supérieure de la Statistique et de l'Analyse de l'Information, Tunisia \\ ${ }^{\mathrm{f}}$ UMR 5569 HydroSciences IRD-CNRS-Université de Montpellier, 163 rue Auguste Broussonnet, 34090 Montpellier, France \\ ${ }^{\mathrm{g}}$ Ecole des Mines d'Alès, LGEI, 6 Avenue de Clavieres, 30319 Alès Cedex, France \\ h Department of Geosciences, Université de Malte, Msida, Malta
}

\section{H I G H L I G H T S}

- Impact of industrial pollutant on cyst abundance and distribution

- Statistical correlation between trace metal and cysts abundance

- Importance of highlighting dinoflagellate cyst assemblage within Bizerte Lagoon

- Levels of inorganic and organic contaminants within Bizerte lagoon
G R A P H I C A L A B S T R A C T

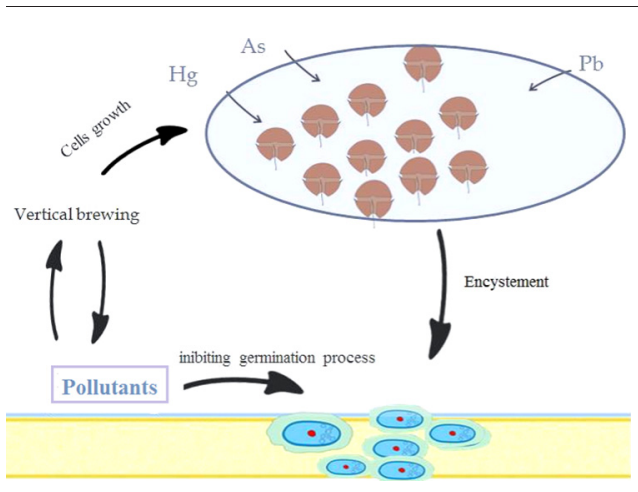

\section{A R T I C L E I N F O}

\section{Article history:}

Received 11 January 2017

Received in revised form 12 March 2017

Accepted 20 March 2017

Available online $\mathrm{xxxx}$

Editor: D. Barcelo

\section{Keywords:}

Dinocyst assemblage

Mediterranean Bizerte Lagoon

Spatial distribution

Toxic/noxious species

\footnotetext{
* Corresponding author.

E-mail address: bibarouma@hotmail.fr (H.Z. Triki).
}

\begin{abstract}
A B S T R A C T
We studied the relationships between sediment industrial pollutants concentrations, sediment characteristics and the dinoflagellate cyst abundance within a coastal lagoon by investigating a total of 55 sampling stations within the Bizerte lagoon, a highly anthropized Mediterranean ecosystem. The sediment of Bizerte lagoon is characterized by a high dinocyst abundance, reaching a maximum value of $2742 \mathrm{cysts} \cdot \mathrm{g}^{-1}$ of dry sediment. The investigated cyst diversity was characterized by the presence of 22 dominant dinocyst morphotypes belonging to 11 genera. Two dinoflagellate species dominated the assemblage: Alexandrium pseudogonyaulax and Protoperidinium claudicans, representing 29 to $89 \%$ and 5 to $38 \%$ of the total cyst abundance, respectively, depending on the station. Seven morphotypes belonging to potentially toxic species were detected, including Alexandrium minutum, A. pseudogonyaulax, Alexandrium catenella/tamarense species complex, Lingulodinium polyedrum, Gonyaulax cf. spinifera complex, Prorocentrum micans and Protoceratium reticulatum. Pearson correlation values showed a positive correlation $(\alpha=0.05)$ between cyst abundance and both water content and fine silt sediment content. Clustering revealed that the highest abundance of cysts corresponds to stations presenting the higher amounts of heavy metals. The simultaneous autoregressive model (SAM) highlighted a significant
\end{abstract}


Organic/inorganic contaminants Interaction pollutants/cysts correlation $(\alpha=0.05)$ between cyst accumulation and two main factors: sediment water content and sediment content for several heavy metals, including $\mathrm{Hg}, \mathrm{Cd}, \mathrm{Cu}, \mathrm{Ni}$ and $\mathrm{Cr}$. These results suggest that the degree of heavy metal pollution could influence cyst accumulation patterns.

\section{Introduction}

Resting cysts are resistance forms produced sexually. They allow dinoflagellates to survive unfavorable environmental conditions, thus playing an important role in the population dynamics of harmful algal species (Anderson and Wall, 1978; Dale, 1983). Their capacity to be preserved in the sediment for long periods provides a reservoir of diversity and a suitable tool to study temporal changes in phytoplankton populations in a given area (Belmonte et al., 1997). Resting cysts are closely involved in the occurrence and spread of toxic blooms. Their distribution and abundance are considered to be valuable predictors of the formation of toxic blooms, particularly in semi-confined areas (Satta et al., 2013; Steidinger and Garcès, 2006; Bravo et al., 2006; Genovesi et al., 2009). A high cyst production rate ensures a continuous supply for the cyst bank and a regular inoculation of the water column (Zmerli Triki et al., 2015a, 2015b; White and Lewis, 1982).

Cyst distribution could be controlled by various factors, including sediment physical characteristics and hydrodynamics. Several studies suggest that cysts act like fine sediment particles and that the highest cyst abundance is correlated with the fine sediment fraction $(<63 \mu \mathrm{m})$ (Anderson et al., 2005; Anglès et al., 2010; Horner et al., 2011). The cyst production rate and abundance are also influenced by many biological and environmental factors (temperature decrease, nutrient deficiency, turbulence). It has been suggested that nutrient supplies discharged through river runoffs from land or re-suspended from bottom surface sediment through upwelling could significantly increase the abundance of dinocysts by promoting diatom biomass increases and, consequently, also of heterotrophic predators such as dinoflagellates and their resting cysts (Thorsen and Dale, 1997; Matsuoka, 1999; Dale, 2001, 2009; Godhe and McQuoid, 2003). At the same time, higher water temperatures increase the vertical stability of the water column, influencing the growth rates and the metabolism of the autotrophic dinoflagellates by inducing indirectly the cyst production at the end of the bloom (Elshanawany et al., 2011; Godhe and McQuoid, 2003).

Some studies showed that trace metals are preferentially associated with the 5-80 $\mu \mathrm{m}$ fraction of plankton, mainly dominated by microphytoplankton (Rossi and Jamet, 2008). Chemical contaminants can affect negatively the metabolic activities of vegetative cells of various phytoplankton species, inhibiting their growth and survival at determined concentrations (e.g., Rai et al., 1998; Mosulén et al., 2003; Wang et al., 2005; Miao and Wang, 2006; Herzi et al., 2013). Until now, most of the ecotoxicological studies conducted on dinoflagellates investigated the effects of contaminants only on vegetative cells. Few studies examined their potential effect on cyst production and abundance (e.g., Pospelova et al., 2005; Godhe and McQuoid, 2003; Aydin et al., 2015; Liu et al., 2012). These authors studied the relationships between resting cyst abundance and the degree of heavy metal contamination, suggesting that trace metals could potentially affect the physiology of dinoflagellates by enhancing resting cyst production rates. Nevertheless, to date, no study to evaluate the potential effect of organic contamination on cyst abundance has been performed. In the present study, we evaluated statistically any possible correlation between resting cyst abundance and the degree of inorganic and organic contaminants in sediment of an anthropized Mediterranean lagoon. For this purpose, a high resolution mapping study was conducted to 1 ) investigate the diversity of the dinoflagellates having relatively high resting cyst densities ( $\geq 50$ cysts $\cdot \mathrm{g}^{-1}$ of dry sediment DS) and to 2 ) measure the concentrations of the main contaminants within the surface sediment, including trace metals, organotin compounds (tributyltin, TBT), Polycyclic aromatic hydrocarbons (PAHs) and polar pesticides (mainly herbicides). Field measurements and sampling were performed within Bizerte lagoon, located along the north-eastern coastline of Tunisia (Mediterranean Sea) which hosts important industrial activities and intense coastal urbanization.

\section{Materials and methods}

\subsection{Study area and sampling}

Bizerte lagoon $\left(37^{\circ} 8^{\prime}-37^{\circ} 14^{\prime} \mathrm{N}, 9^{\circ} 46^{\prime}-9^{\circ} 56^{\prime} \mathrm{E}\right.$ ) is a shallow ( $8 \mathrm{~m}$ average water depth) area covering $128 \mathrm{~km}^{2}$ (Fig. 1). It's economically important, holding nine shellfish farms (Mytilus galloprovincialis, Ostrea edulis and Crassostera gigas). In the Bizerte lagoon, the surface current is stronger than the bottom current at the northern, western and southern parts and is relatively weak in the central part of the lagoon (Bejaoui et al., 2008). The phytoplankton assemblage is mainly represented by 51 diatom taxa and 31 dinoflagellate taxa (Bellakhal-Fartouna and Daly Yahia-Kéfi, 2004). In November 2007, a bloom of Alexandrium catenella was recorded in Bizerte Lagoon, with observed cell concentrations reaching levels of up to $20 \cdot 10^{4}$ cells $\cdot \mathrm{L}^{-1}$. No additional blooms were recorded since 2007 (Turki et al., 2007).

The watershed of the lagoon currently hosts 277 industrial units (petrochemical, textiles, food, steel and plastics processing) and receives numerous industrial runoffs, either directly or through river discharge. The most polluting industries are the cement-production and oil-refinery ones along the northern shores, and shipbuilding, ship-repair and steel-production ones along the southwestern shores. Land bordering the Southeast sector is mainly exploited for intensive agriculture featuring cereal crops (7800 ha), vegetables (3400 ha) and tree crops (500 ha) (Mansouri, 1996). The main pollutants released in this lagoon are nitrates, phosphorus and trace metals, including iron, zinc and arsenic (Comete-IHE, 2003). TBT and PAH contamination levels within the lagoon are considered to be low to moderate (Mzoughi et al., 2005; Barhoumi et al., 2014b). In terms of pesticide contamination, Organochlorine pesticides (OCPs) were detected within sediments (Barhoumi et al., 2014a; Ben Salem et al., 2016) with iodosulfuron, mesosulfuron, 2,4-dichlorophenoxyacetic acid (2,4 D), glyphosate, and fenoxaprops being the most abundantly-recorded herbicides, and tebuconazole and epoxiconazole being the most abundant fungicides, and deltamethrin being the most widely-used insecticides.

\subsection{Sediment sampling and analysis}

Sediment sampling was carried out at 55 stations (Fig. 1) during July-August 2012 using cylindrical cores (26 cm long, $4 \mathrm{~cm}$ diameter) operated by SCUBA divers. The sampling station depth ranged from 4.5 to $16 \mathrm{~m}$. Only the superficial sediment layer $(0-3 \mathrm{~cm})$ was used. Three replicates per station were collected and then stored in darkness at $4{ }^{\circ} \mathrm{C}$. The sediment mean particle diameter size was analyzed using the laser particle sizer Malver Master sizer TM LSE (details are provided in Zmerli Triki et al., 2014).

\subsubsection{Organic matter (OM) and water content $\left(\mathrm{H}_{2} \mathrm{O} \%\right)$ analysis}

Wet sediment samples from Bizerte lagoon (Ww) was dried for 7 days at $60{ }^{\circ} \mathrm{C}$ to evaluate their $\mathrm{H}_{2} \mathrm{O} \%$. The resulting dry sediment was weighted $(\mathrm{Wd})$, then heated at $450{ }^{\circ} \mathrm{C}$ for $12 \mathrm{~h}$ to eliminate any $\mathrm{OM}$. The final weight was registered as $\mathrm{Wd} 1$. The sediment water and 
organic content were calculated as follows: $\mathrm{H} 2 \mathrm{O} \%=[(\mathrm{Ww}-\mathrm{Wd})$ $* 100] / \mathrm{Ww}, \mathrm{OM} \%=[(\mathrm{Wd}-\mathrm{Wd} 1) * 100] / \mathrm{Wd} 1$.

\subsubsection{Contaminant analyses}

They were carried out for 55 sampling stations, for trace metals and butylin compounds, and for over 20 sampling stations for PAHs and pesticides, since insufficient sediment was available to conduct all the chemical analyses for all the sampling sites.

2.2.2.1. Trace metal analysis. Trace metals were analyzed through inductively coupled plasma mass spectrometry (ICP-MS) using a X-Series II ICPMS equipped with a collision cell technology chamber (Thermo Fisher Scientific). Digestion of samples was carried out in a microwave oven (Discover SP-D Plus, CEM ${ }^{\circledR}$ ) using the U.S. EPA method SW 846-3052. In brief, $100 \mathrm{mg}$ of sediment samples were digested using a mixture of $2 \mathrm{ml}$ $\mathrm{HF}$ (Suprapur 40\%, Merck Millipore ${ }^{\circledR}$ ) and $4 \mathrm{ml} \mathrm{HNO}_{3}$ (Suprapur 65\%, Merck Millipore $\left.{ }^{\circledR}\right)$. Hg analysis was performed using the direct mercury analyzer Milestone DMA-80 (Milestone $\mathrm{GmbH}$, Germany) according to U.S. EPA 7473 method (Mercury in Solids and Solutions by Thermal Decomposition, Amalgamation, and Atomic Absorption Spectrophotometry). Detection limits $\left(\mu \mathrm{g} \cdot \mathrm{g}^{-1}\right)$ for trace metals adopted in this study are: 0.00600 for $\mathrm{Hg}, 0.02620$ for $\mathrm{Cd}, 0.06638$ for $\mathrm{As}, 0.05631$ for $\mathrm{Cu}$, 0.05631 for $\mathrm{Cu}, 0.05578$ for $\mathrm{Ni}, 0.06092$ for $\mathrm{Pb}$ and 0.07220 for Cr. Results were classified according to Long et al. (1995) into three categories, in terms of their degree of adverse biological effects: rarely ( $<$ Effects Range Low (ERL), occasionally (ERL-ERM) and frequently (> Effects Range Medium (ERM).

2.2.2.2. Butyltin compounds. The tin-containing compounds TriButyltin (TBT), DiButylin (DBT) and MonoButyltin (MBT) were analyzed using a gas chromatograph (Focus GC - Thermo Fisher Scientific ${ }^{\circledR}$ ) coupled with an inductively-coupled plasma mass spectrometer (ICP-MS X Series II-Thermo Fisher Scientific $\left.{ }^{\circledR}\right)$. The butyltin compounds analysis steps included a gentle extraction to avoid Sn speciation modification, followed by a derivatization step and extraction in the organic phase (isooctane), as described in Carlier-Pinasseau et al. (1996). The certified reference marine sediment from the Canadian National Research Council (National Research Council NRC, Canada), PACS-2, was used to check for analytical precision and accuracy in trace metals and organotin speciation.

2.2.2.3. Pesticide analysis. The ASE extraction (Dionex, France) was carried out for 15 min with a solvent mixture (hexane/acetone (50/50)) at $120^{\circ} \mathrm{C}$ and at $1500 \mathrm{psi}$ of nitrogen. The internal standard (Atrazine d5) was added to the sample prior the extraction step. After extraction, the extract was cleaned on a Strata SAX (8B-S008-JCH). The elution step was carried out with $3 \mathrm{ml}$ of $\mathrm{MeOH}$ and with $3 \mathrm{ml}$ of $\mathrm{CH}_{2} \mathrm{Cl}_{2}$ so to recover hydrophobic compounds. Purified extracts were completely evaporated under a gentle stream of nitrogen and were then dissolved in $1.5 \mathrm{ml}$ of acetonitrile. All sample extracts were spiked before analysis with 120 $\mu \mathrm{l}$ of the deuterated internal standard simazine-d10 $\left(1.2 \mathrm{mg} \cdot \mathrm{l}^{-1}\right)$ and analyzed through HPLC-MS/MS.

Pesticide analysis was performed through HPLC-MS/MS using an Alliance HPLC system (Waters Series 2695). Analytic separation was achieved with a Kinetex C18 analytical column (100 $\mathrm{mm} * 4.6$ I.D * $260 \AA$ A , Phenomenex). Acetonitrile (A) and ultrapure water (B), both with $0.05 \%$ formic acid, were used as mobile phases at the constant flow rate of $0.4 \mathrm{ml} \cdot \mathrm{min}^{-1}$. The Linear gradient was started at $40 \%$ for $0.2 \mathrm{~min}$, ramped to $80 \%$ for $8 \mathrm{~min}$, then to $100 \%$ for $1 \mathrm{~min}$ and finally back to the initial conditions for $2 \mathrm{~min}$. A triple quadrupole mass spectrometer (Micromass Quatro microTM, Waters) equipped with an electrospray ionization source (ESI) was used as the detector device. The spectrometer operated in positive ESI mode under the following conditions: capillary voltage $(3.5 \mathrm{kV})$, source temperature $\left(120^{\circ} \mathrm{C}\right)$, desolvation temperature $\left(300{ }^{\circ} \mathrm{C}\right)$, drying $(600 \mathrm{l} / \mathrm{h})$, and nebulization gas (N2) flow (30 l/h). Argon was used as the collision gas. Acquisition for each compound was performed in the multiple reaction-monitoring mode (MRM). Two transitions were retained: one was used for the quantification aspect and the other was used for the confirmation aspect.

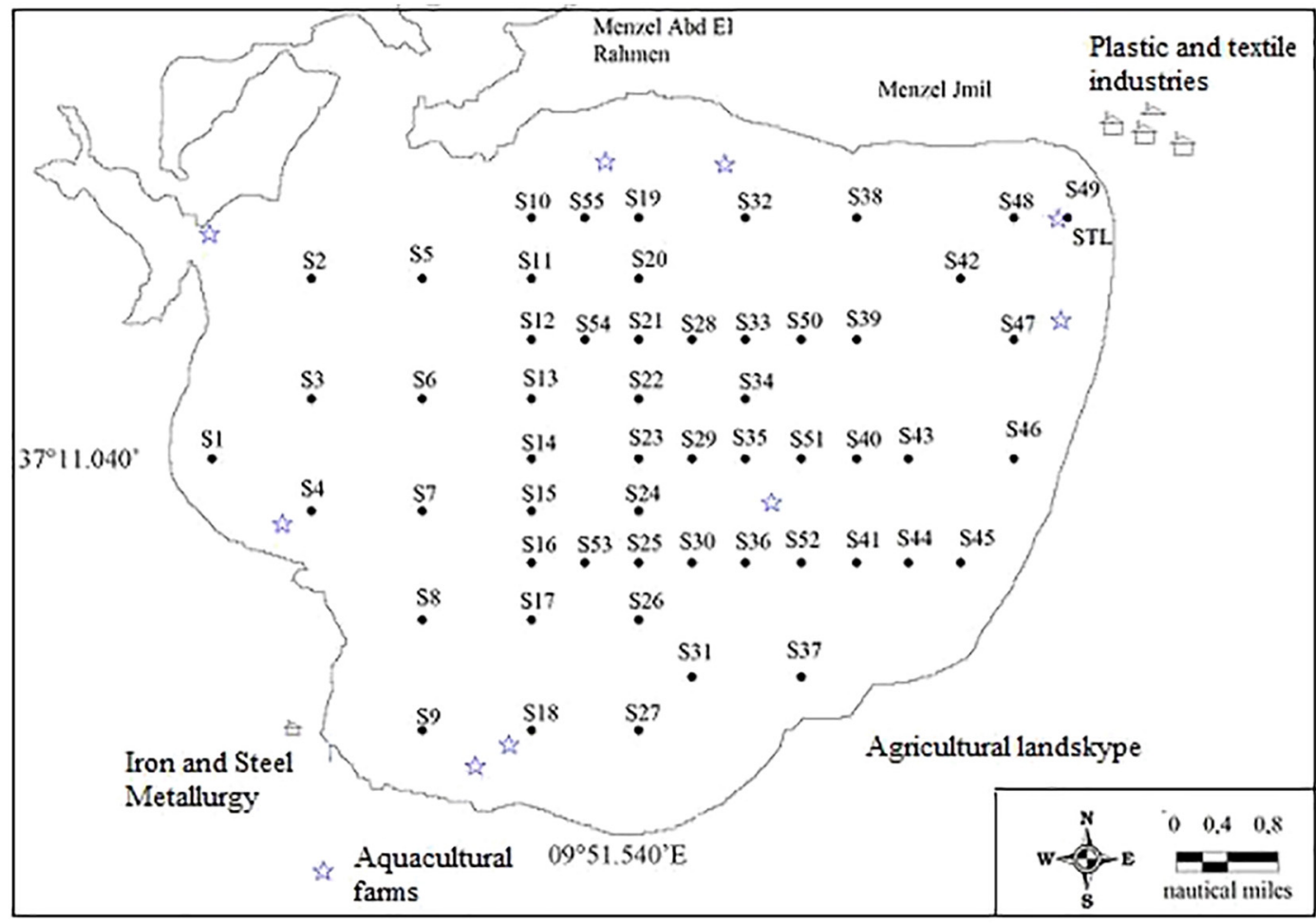

Fig. 1. The Bizerte Lagoon sampling stations adopted within this study. 
2.2.2.4. PAH analysis. The ASE ( 350 Dionex, France) extraction was carried out for 15 min with a solvent mixture (hexane/acetone (50/50)) at $120^{\circ} \mathrm{C}$ and at 1500 psi of nitrogen. The extract was then kept in contact with copper powder for $48 \mathrm{~h}$ in order to remove sulfur interferences. After extraction, the extract was cleaned on a Strata Florisil (FLPR, 32138). The elution step was carried out with $5 \mathrm{ml}$ Hexane. Purified extracts were analyzed through a GC-MS (Varian 450-GC and Varian $240 \mathrm{MS}$ ) working in the electron impact mode at $70 \mathrm{eV}$. A DB-5 ms (Agilent) chromatographic column ( $30 \mathrm{~m}, 0.25 \mathrm{~mm}$ ID and $0.25 \mu \mathrm{m}$ of film thickness) was used. The Helium flow rate was fixed at $1 \mathrm{ml} \cdot \mathrm{min}^{-1}$. The extract $(2 \mu \mathrm{l})$ was injected in the chromatographic column with a PTV 1079 injector maintained at $300{ }^{\circ} \mathrm{C}$. The initial oven temperature was increased from $120{ }^{\circ} \mathrm{C}(1 \mathrm{~min})$ to $160{ }^{\circ} \mathrm{C}$ at 6 ${ }^{\circ} \mathrm{C} \mathrm{min}^{-1}$ (holding for $5 \mathrm{~min}$ ); then the temperature was subsequently increased to $310^{\circ} \mathrm{C}$ at $10^{\circ} \mathrm{C} \mathrm{min}^{-1}$ (holding for $5 \mathrm{~min}$ ). The MS transfer line and the ion source were retained at $310^{\circ} \mathrm{C}$ and at $220^{\circ} \mathrm{C}$, respectively. Acquisition was carried out in the single ion monitoring (SIM) mode using characteristic ions as standards for each target analyte. Internal standard calibration was performed with Acenaphthylene-D8, Acenaphthene-D10, Naphthalene-D8, Fluoranthene-D10 and Phenanthrene-D10. The whole procedure (extraction, clean up and GC/MS analysis) was validated using the certified sediment sample RTCCRM104-050 (LGC). PAH level results were classified according Long et al. (1995) and the detection limit is reported in Supplementary Table 4.

\subsection{Resting cyst analyses}

\subsubsection{Resting cyst extraction}

For resting cyst extraction, $1 \mathrm{~g}$ of wet sediment was re-suspended in Filtered Sea Water (FSW), sonicated ( $3 \mathrm{~min}$ ) and then sieved through 100 and $20 \mu \mathrm{m}$ mesh sieves. The fraction recovered on the 20 $\mu \mathrm{m}$ mesh sieve was centrifuged at $3000 \mathrm{rev} \cdot \mathrm{min}^{-1}$ for $10 \mathrm{~min}$ at $4{ }^{\circ} \mathrm{C}$, to recover the pellet containing dinocysts. Extraction was based on the gradient-density method by adding Polytungstate Solution (Bolch, 1997) and centrifuging the pellet again. The supernatant containing the cysts was then sieved through a $20 \mu \mathrm{m}$ mesh and washed thoroughly to eliminate residues of PST.

\subsubsection{Resting cyst identification and quantification}

The taxonomic identification of resting cysts (RCs) is difficult and several steps such as isolation, germination and culture implementation are often required to confirm the identity of each species. Only the most abundant living dinocysts encountered within the sampled sediment were quantified and identified. The taxonomic identification of cysts was made according to the Matsuoka and Fukuyo (2000) method which is based on the photonic microscopic observation (Esselte Leitz $\mathrm{GmbH}$, Germany) of morphological characteristics of RCs and also on germination experiments. Given the difficulty of identifying species belonging to the Spinifera group without using molecular tools, all related species were grouped together and identified collectively as Spinifera complex. A. pseudogonyaulax cysts were represented by different morphotypes which could lead to mis-identification; to avoid this, all related morphotypes were isolated and taxonomic identification was only confirmed after germination (Zmerli Triki et al., 2016). Cyst quantification was performed in duplicate according to the Uthermol method using a $3 \mathrm{ml}$ sedimentation cell. Cyst densities were assessed per gram of dry sediment.

\subsubsection{Germination experiments and culturing}

To confirm the taxonomic identity of RCs, they were isolated individually with a micropipette and placed into wells onto a 96-culture plate (Nunc ${ }^{\mathrm{TM}}$ Delta surface) filled with.

Enriched Natural Sea Water (ENSW) culture medium (Harrison et al., 1980) and incubated at standard conditions $\left(20^{\circ} \mathrm{C}\right.$, Salinity 36,100 $\mu \mathrm{mol} \cdot \mathrm{m}^{-2} \cdot \mathrm{s}^{-1}$ irradiance and $12 \mathrm{~h}: 12 \mathrm{~h}$ light: dark). Cyst germination was examined daily and those exhibiting unsuccessful incubation were discarded after 30 days. Germling cell identification was done according to Drebes (1974), Delgado and Fortuno (1991), Steidinger and Tangen (1996). Cultures of the potentially toxic species Alexandrium pseudogonyaulax and of the abundant species Scrippsiella rotunda were established from excysted cells.

\subsection{Statistical analyses}

The degree of RC diversity was investigated using the ShannonWiener's index ( $\mathrm{H}^{\prime}$ bits $\cdot$ ind $^{-1}$ ) (Shannon and Weaver, 1949) and Pielou's evenness (J) (Pielou, 1966), following these equations:

$\mathrm{H}^{\prime}\left(\right.$ bits $\cdot$ ind $\left.^{-1}\right)=-\sum[(\mathrm{ni} / \mathrm{N}) * \ln (\mathrm{ni} / \mathrm{N})]$

$\mathrm{J}^{\prime}=\mathrm{H}^{\prime} / \mathrm{H}^{\prime} \max$

where H'max $=\log \mathrm{S}$ (S: total species number in the sample), ni: number of individuals of a species in the sample and $\mathrm{N}$ : total number of individuals in the sample.

The Principal Component Analysis (PCA) test was performed to investigate the importance of different environmental factors in determining the distribution of cyst abundance within the sampling area. Hierarchical Cluster analyses (HCA) was performed in order to group sampling stations on the basis of the average heavy metal pollution level they exhibit using the Ward aggregation method. A hypothesized organized spatial structure for resting cyst distribution was investigated using a spatial autocorrelation test, the Moran's I index which is based on a Delaunay triangulation. This index was computed using Moran.mc function from the spdep R-package. A Simultaneous Autoregressive (SAR) model was developed to analyze the predictive power of pollutant levels in the sediment for determining the resting cyst abundance. All statistical tests were performed using R software (available online at: http://www.r-project.org) and distribution maps for different pollutants and dinocysts were generated using the MapInfo professional 10.0 software.

\section{Results}

\subsection{Sediment texture and contaminant levels}

The texture results for benthic sediment from Bizerte lagoon are summarized in Supplementary Table 1 . Sediment was mainly composed of the sandy-mud and muddy fractions. The fine fraction $(<63 \mu \mathrm{m})$ was the prevailing one (Fig. 2), ranging between 50.48 and $97.6 \%$ of sample

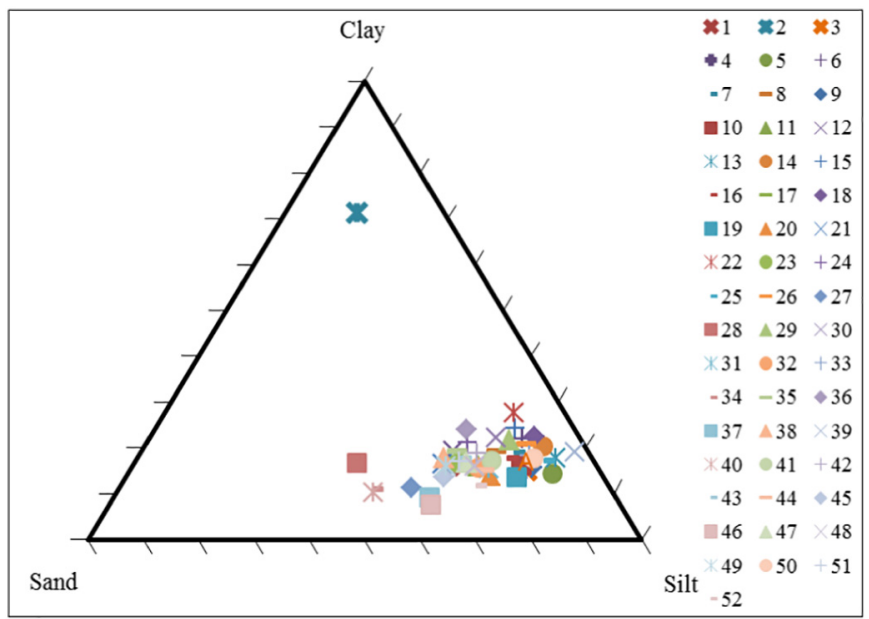

Fig. 2. Shepard and Folks representation of Bizerte lagoon sediment structure. 


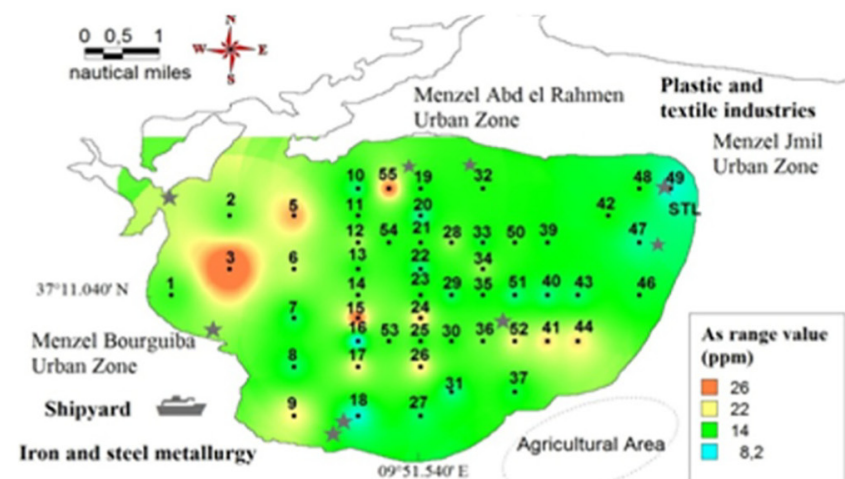

$\star$ Aquacultural farms

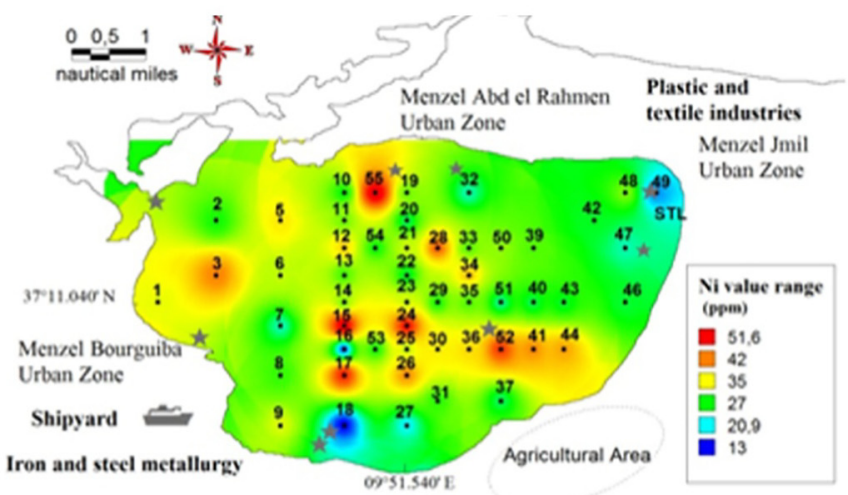

$\star$ Aquacultural farms
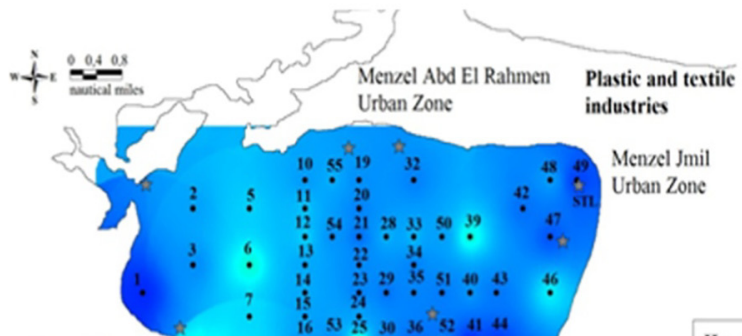

Menzel Bourguiba Urban zone

Shipyard

Iron and steel metallurgy

$$
\star \text { Aquacultural f } A \text { gricultural area }
$$
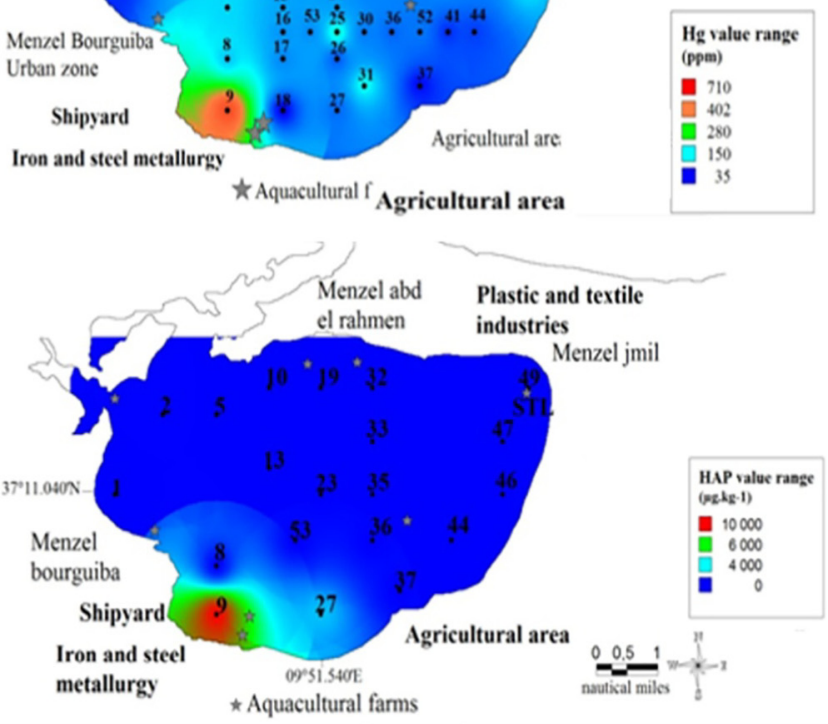

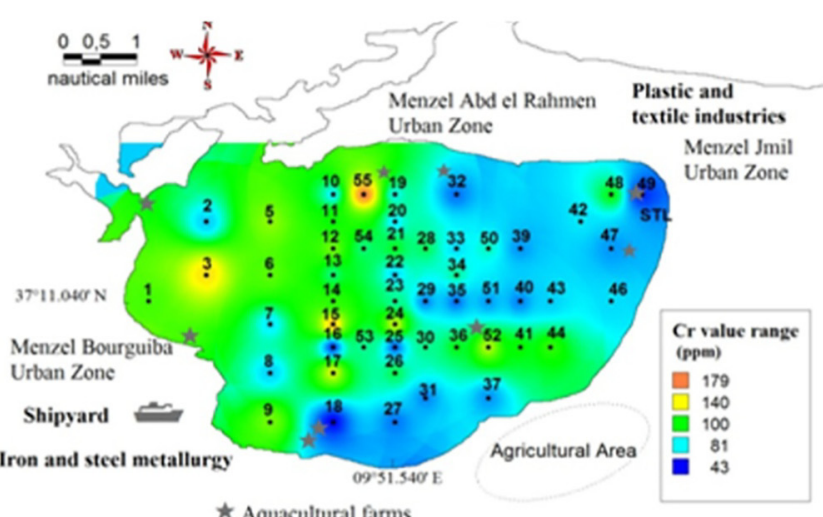

$\star$ Aquacultural farms

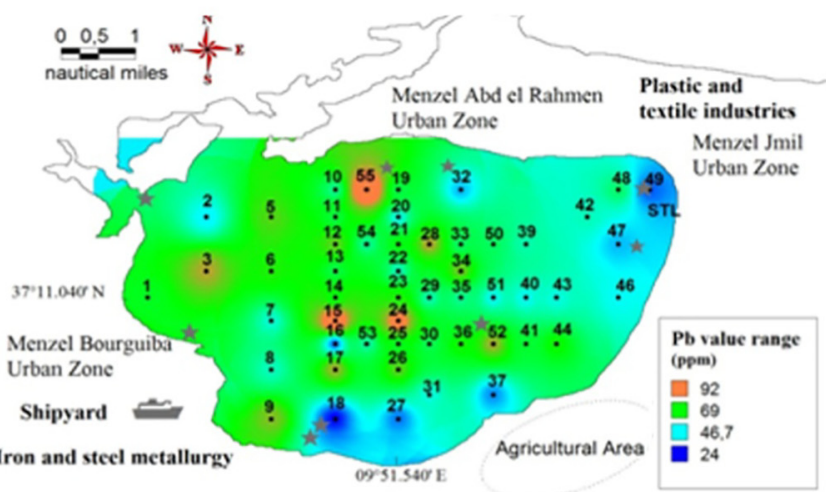

$\star$ Aquacultural farms
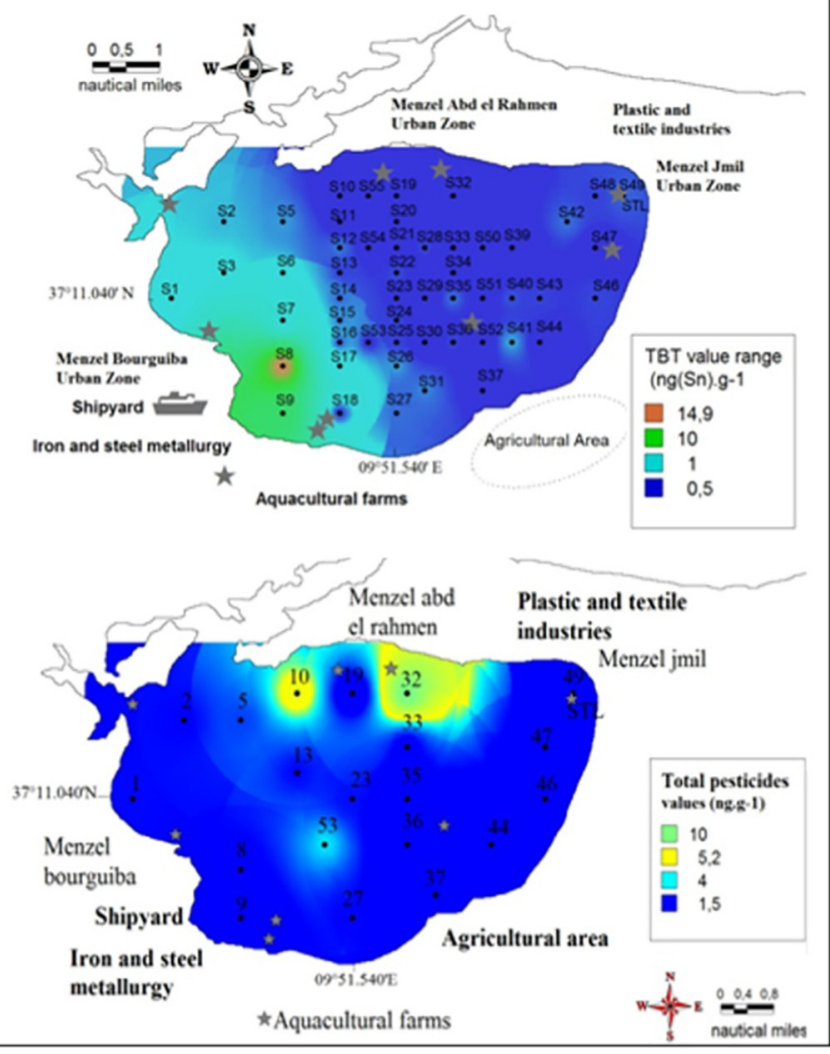

Fig. 3. Trace metals, TriButyltin, polycyclic aromatic hydrocarbon and polar pesticides levels and distribution within surface sediment of Bizerte lagoon. 


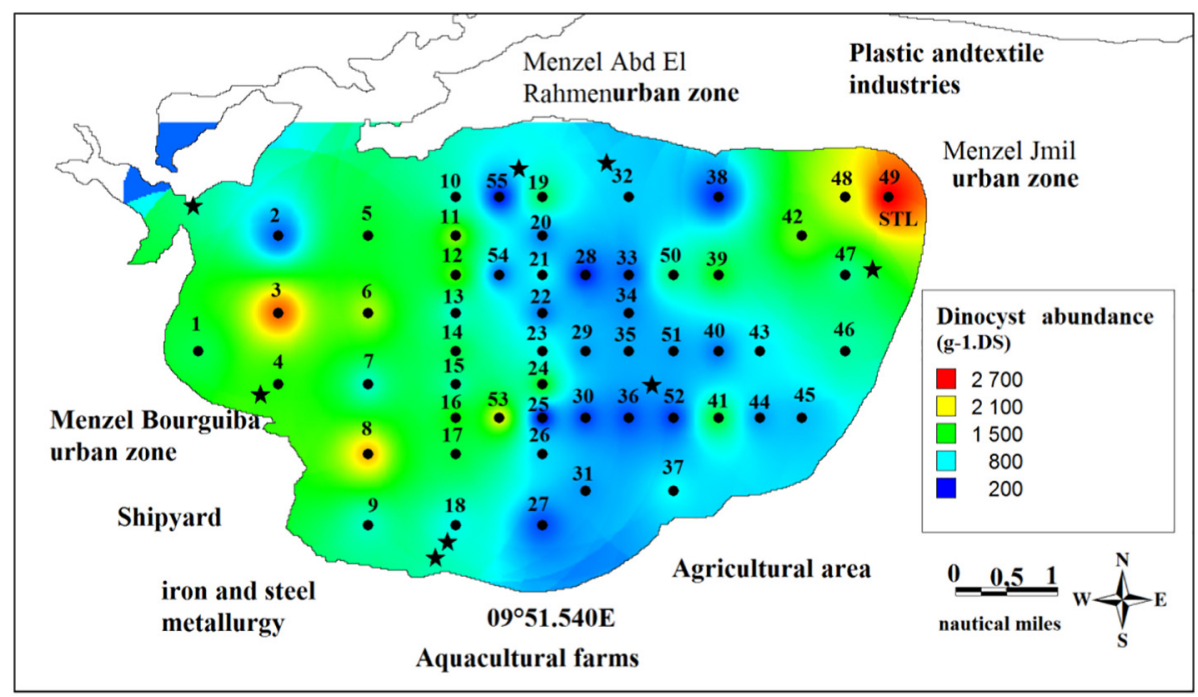

Fig. 4. Dinocyst (cysts $\cdot \mathrm{g}^{-1}$ dry sediment) distribution in the sediment of Bizerte lagoon.

composition in terms of weight, and was mainly represented by silt $(60.56 \pm 3.5 \%)$, whereas the clay fraction was less abundant $(17.99 \pm$ 8.46\% - Zmerli Triki et al., 2014).

Industrial contamination within Bizerte lagoon benthic sediments was mainly represented by trace metals and TBT. The southern sectors of the lagoon were the main areas impacted by $\mathrm{Hg}$ (171-524 ppm), total butyltin (23.9-39.76 $\left.\mathrm{ng}(\mathrm{Sn}) \cdot \mathrm{g}^{-1}\right)$ and PAH (3042-9948 $\left.\mathrm{ng} \cdot \mathrm{g}^{-1}\right)$ contamination (Fig. 3, Supplementary Tables 2 and 3). All the trace metals investigated in this study were recorded within all the lagoon sampling sites. Cd (0.10-0.6 ppm), Cu (8.63-36.62 ppm) and Zn (93$408 \mathrm{ppm}$ ) levels detected in Bizerte lagoon benthic sediments (Supplementary Table 2) are unlikely to cause adverse biological effects. Recorded values for $\mathrm{Cd}$ and $\mathrm{Zn}$ were always below the ERL, at $1.2 \mathrm{ppm}$ and $410 \mathrm{ppm}$, respectively. Conversely, high concentrations for $\mathrm{Cu}$ were registered and were above the ERL value of 34 . Mercury contamination was lower than the ERL at most sampling stations along the northern side of the lagoon, whereas high values exceeding the ERL (150 ppm) were recorded (175.68 and $524 \mathrm{ppm}$ ) within the southern part. Four contaminants ( $\mathrm{As}, \mathrm{Cr}, \mathrm{Pb}, \mathrm{Ni}$ ) were observed at most sampling stations, with contamination levels exceeding the ERL proposed by Long et al. (1995) (Fig. 3). Arsenic (As) levels ranged between 7.9 and $30.4 \mathrm{ppm}(\mathrm{ERL}=8.2 \mathrm{ppm})$, Nickel $(\mathrm{Ni})$ values ranged between 12.83 and $56.74 \mathrm{ppm}$ (ERL $=20.9 \mathrm{ppm}$ ), Lead $(\mathrm{Pb})$ levels from 23.87 to $123.92 \mathrm{ppm}(\mathrm{ERL}=46.7 \mathrm{ppm})$ and finally $\mathrm{Cr}$ values ranged between 43.35 and $179.2 \mathrm{ppm}(\mathrm{ERL}=81 \mathrm{ppm})$. High values for Ni were registered at four stations $(15,17,24$ and 54$)$, with respective values of $56.48,49.63,52$ and $56.74 \mathrm{ppm}(>\mathrm{ERM}=51.6 \mathrm{ppm})$.

Moderate total butyltin levels ( $\sum \mathrm{BT}$ ) were recorded, with concentrations falling in the $4.76-39.76 \mathrm{ng}(\mathrm{Sn}) \cdot \mathrm{g}^{-1}$ range. MonoButyltin (MBT) levels ranged between 3.86 and $18 \mathrm{ngSn} \cdot \mathrm{g}^{-1}$, DBT values ranged between $0.17-6.61 \mathrm{ngSn} \cdot \mathrm{g}^{-1}$ and finally the range of TBT levels was that of $0.14-14.91 \mathrm{ng}(\mathrm{Sn}) \cdot \mathrm{g}^{-1}$. The full pollutant contamination levels recorded within the Bizerte lagoon benthic sediments are shown in Supplementary Tables 2, 3 and 4.

The total PAHs measure comprises the sum concentration of the 16 parent PAHs. PAHs contaminants were present at $45 \%$ of the sampled stations within Bizerte lagoon and were mainly localized along the southern part of the lagoon. Stations 2, 5, 8, 10, 13 and 47 were slightly

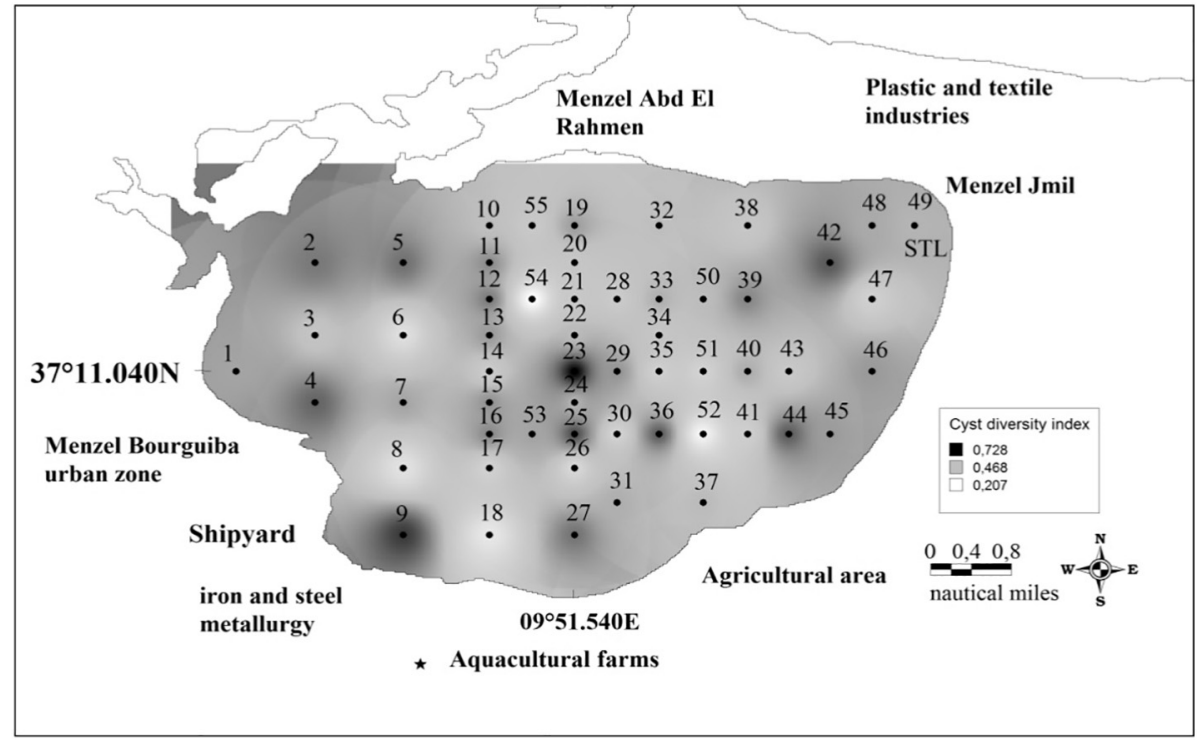

Fig. 5. Dinoflagellates resting cyst diversity index within Bizerte lagoon. 
contaminated with $\sum$ PAHs values, with concentrations ranging from 2.3 to $49.75 \mathrm{ng} \cdot \mathrm{g}^{-1} \mathrm{DS}$, whereas stations 9 and 27 were highly contaminated (9949 and $3043 \mathrm{ng} \cdot \mathrm{g}^{-1}$ DS, respectively). PCB contamination was absent all over the lagoon and pesticides analysis revealed that alachlor and DCPU were the most abundant pesticides present within the sediment. DCPU ranged between 0.35 and $1.1 \mathrm{ng} \cdot \mathrm{g}^{-1}$ DS and alachlor ranged between 0.67 and $4.95 \mathrm{ng} \cdot \mathrm{g}^{-1}$ DS.

\subsection{Dinocyst distribution and abundance}

The spatial distribution of dinocysts in the benthic sediment of Bizerte lagoon is shown in Fig. 4. The highest cyst abundance was that of 2742 cysts $\cdot \mathrm{g}^{-1} \mathrm{DS}$, recorded at station 49 and the lowest one was 203 cysts $\cdot \mathrm{g}^{-1} \mathrm{DS}$ recorded at station 25 . Shannon-Wiener's diversity index values $\left(\mathrm{H}^{\prime}\right)$ ranged between 0.21 and 0.73 bits. ind ${ }^{-1}$ (Fig. 5). $\mathrm{H}^{\prime}$ values $<0.5$ bits $\cdot$ ind $^{-1}$ are normally associated with the dominance of biotic assemblages by a relatively small number of taxa. The low $\mathrm{H}^{\prime}$ index values recorded in our study can be attributed to high densities of $A$. pseudogonyaulax and $P$. claudicans. This was also confirmed by low values obtained for the Pielou equitability (evenness) index (Table 2).

In the laboratory, germination occurred mostly during the first three days of incubation. Successful excystment of most brown (the prevailing cyst colour) cysts frequently gave rise to motile cells belonging to the genus Protoperidinium, whereas excystment of rounded, colorless and walled cysts gave rise to motile stages of Alexandrium vegetative cells. Dinocyst assemblage was mainly represented by two groups: Peridiniales (33\%) and Gonyaulacales (67\%). A total of 22 cysts morphotypes representing 11 genera belonging to the following 4 orders were recorded within the entire Bizerte Lagoon sediment sampling area (Table 3): Peridiniales (Fig. 6), Gonyaulacales (Fig. 7), Gymnodiniales and Prorocentrales (Fig. 8). Two species dominated the dinoflagellate assemblage: A. pseudogonyaulax (29-89\% of total RCs) and $P$. claudicans (5-38\% of total RCs). A. pseudogonyaulax, the most abundant species, was present all over the lagoon and contributed significantly to the total cyst abundance.

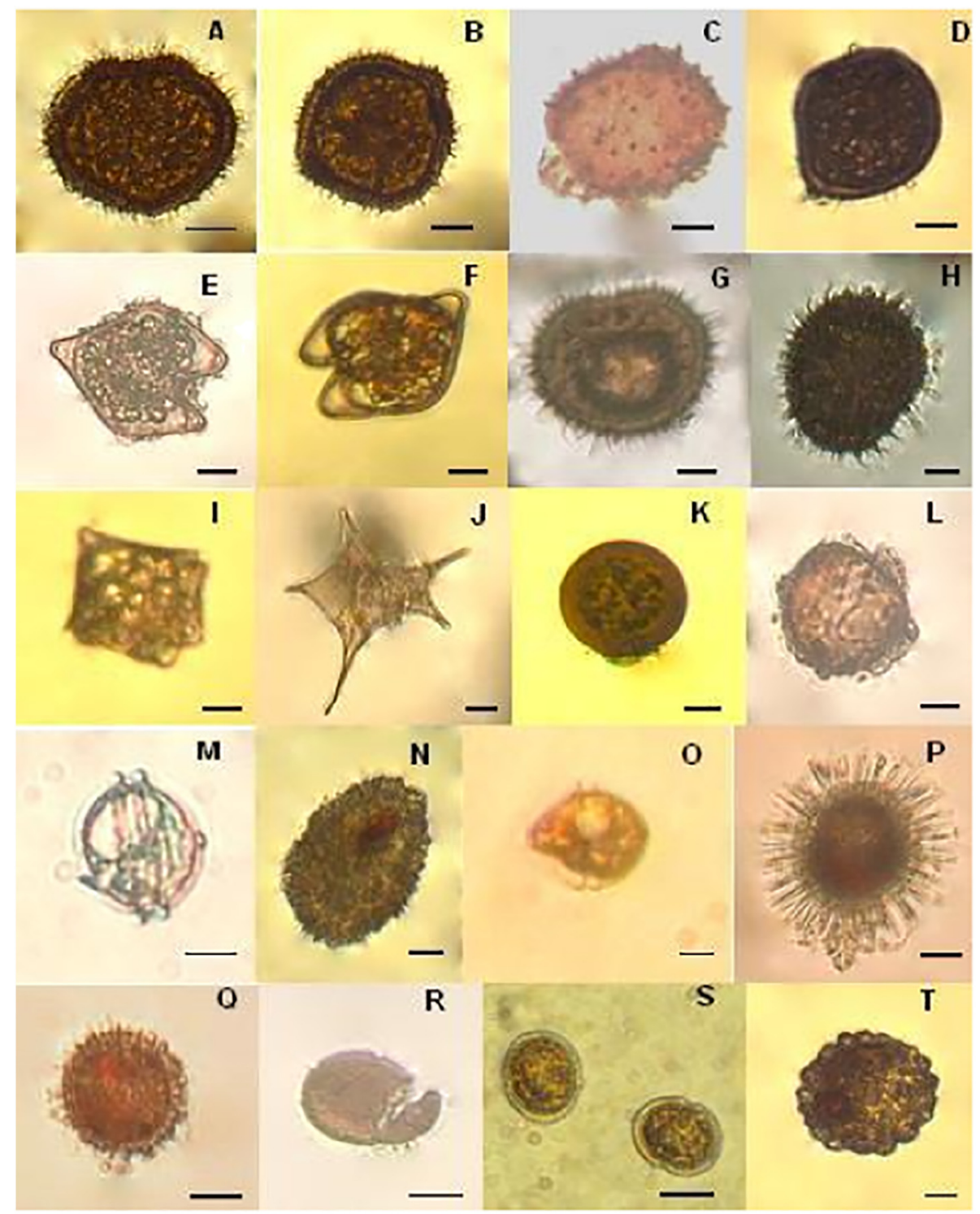

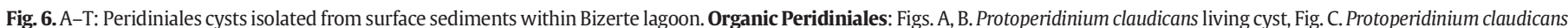

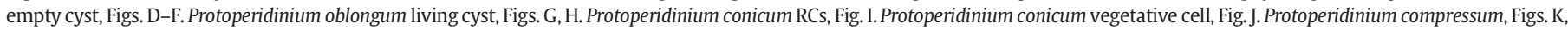

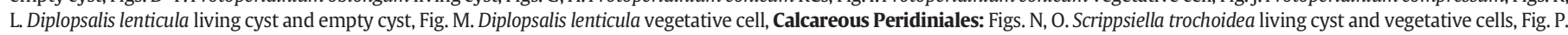
Scrippsiella cf. ramonii, Fig. Q. Scrippsiella cf. precaria, Fig. R. Scrippsiella rotunda, Fig. S. vegetative cells of Scrippsiella rotunda, Fig. T. Ensiculifera sp. Scale bar (10 $\mu$ m). 


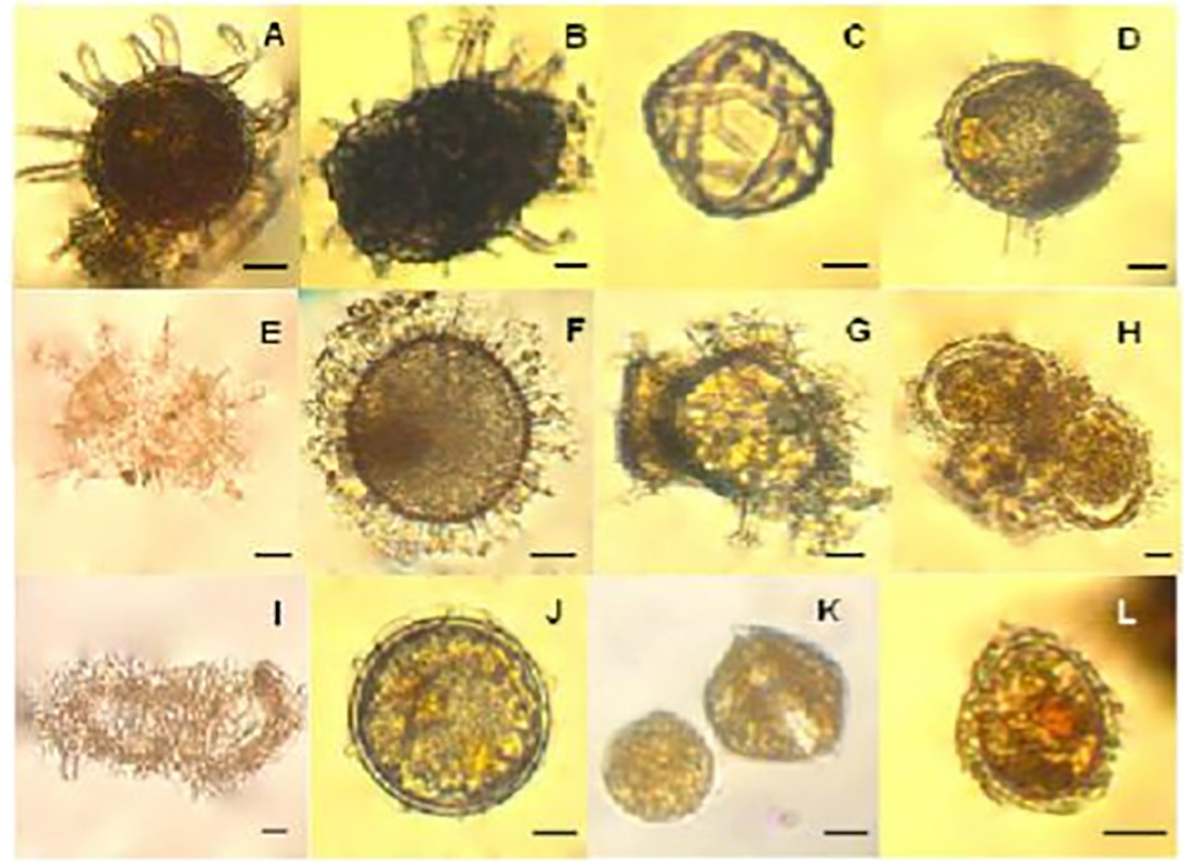

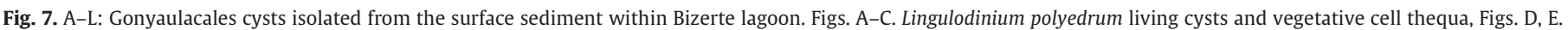

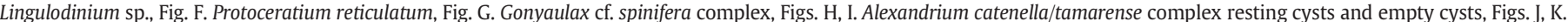
Alexandrium pseudogonyaulax resting cyst and vegetative, Fig. L. Alexandrium minutum resting cyst. All scale bar (10 $\mu \mathrm{m})$.

\subsection{Correlations between chemical contamination and cyst abundance}

The Pearson correlation analysis revealed a positive correlation between cyst abundance and sediment water content $(\alpha=0.01)$ and sediment fine silt content ( $\alpha=0.05$ ). Results are presented in Table 1. PCA was performed to investigate any correlation between the RC densities (considered as a supplementary factor), the sediment characteristics (texture, organic matter, $\mathrm{H}_{2} \mathrm{O}$ percentage) and the contaminant concentrations (Fig. 9). Axes 1 and 2 accounted for $53.2 \%$ of this correlation. PC2 explained the highest part of the correlation (39.6\%) and was mainly represented by trace metal concentrations. PC1 axis was mainly represented by sediment characteristics. Hierarchical clustering on stations based on RC abundance and contaminants revealed a correspondence between the highly polluted stations and the highest RC abundances (Fig. 10). The first cluster showed a mean abundance of $1114 \mathrm{cyst} \cdot \mathrm{DS}^{-1}$ (Sd \pm $\left.660 \mathrm{cyst} \cdot \mathrm{DS}^{-1}\right)$, the second cluster of $955 \mathrm{cyst} \cdot \mathrm{DS}^{-1}$ (Sd \pm 629 cyst.DS ${ }^{-1}$ ) and the third one of 1015 cyst.DS ${ }^{-1}$ (Sd \pm 559 cyst $\left.\cdot \mathrm{DS}^{-1}\right)$. Since Moran I index values revealed a strong degree of co-linearity between the stations, we applied Simultaneous Autoregressive Models (SAR) to remove this spatial autocorrelation in the residuals, and a backward stepwise method was performed to retain the most significant variables in explaining observed total cyst densities. The final SAR model was highly statistically significant $(\alpha=0.05$, $P$-value $=0.0335$ ) and revealed six explanatory environmental factors as shown in the following equation:

Total cyst density (cyst. $\left.\mathrm{g}^{-1} \mathrm{DS}\right)=13.43 \mathrm{Cr}-2.941 \mathrm{Hg}-2566 \mathrm{Cd}$ $+82.25 \mathrm{Cu}-66.37 \mathrm{Ni}+23.67 \mathrm{H}_{2} \mathrm{O}$.

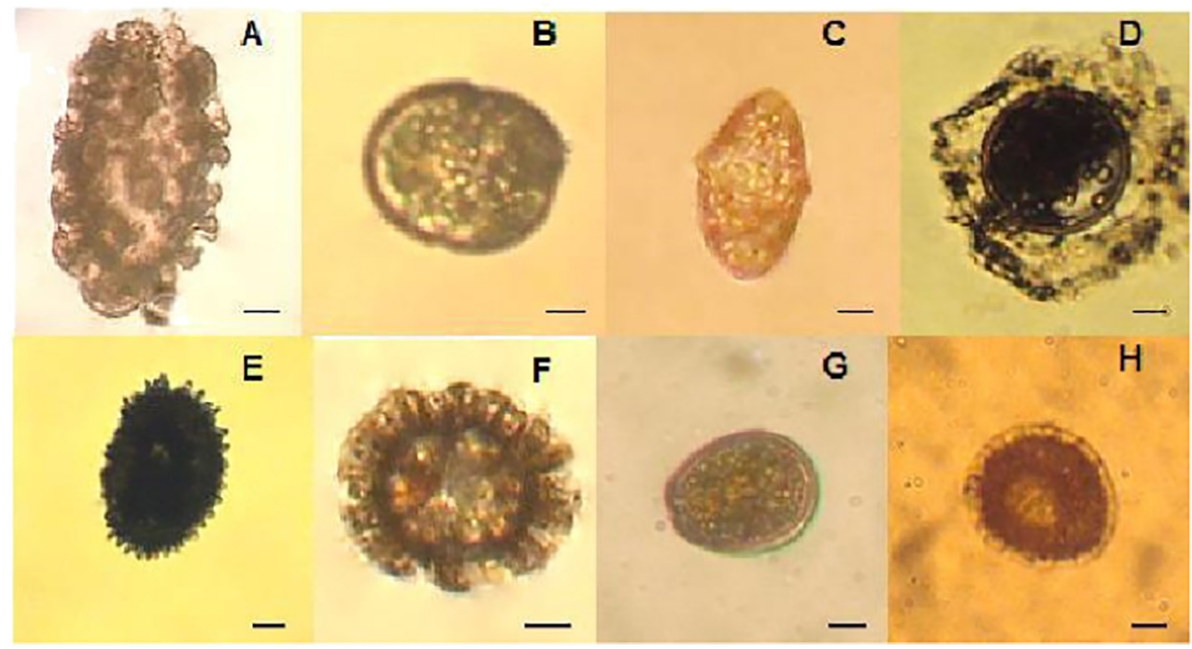

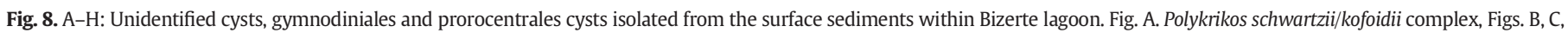
Gymnodinium spp. vegetative cells germinated from sediment, Fig. D. Gymnodinium sp., Figs. E, F, H. unidentified cysts, Fig. G. Prorocentrum cf. micans. Scale bar (10 $\mu$ m). 
Table 1

Correlation coefficient between resting cysts (RCs) abundance and sediment characteristics.

\begin{tabular}{lll}
\hline & Pearson correlation & Significance \\
\hline RCs density & 1 & \\
Water content \% & $\mathbf{0 . 4 1 4}^{\mathrm{a}}$ & $\mathbf{0 . 0 0 2}$ \\
Organic matter $(\mathrm{OM} \%)$ & -0.130 & 0.343 \\
Fine clay $(0-2 \mu \mathrm{m})$ & -0.142 & 0.302 \\
Coarse clay $(2-4 \mu \mathrm{m})$ & -0.147 & 0.283 \\
Fine silt $(4-30 \mu \mathrm{m})$ & $\mathbf{0 . 2 6 9}^{\mathrm{b}}$ & $\mathbf{0 . 0 4 7}$ \\
Coarse silt $(30-63 \mu \mathrm{m})$ & 0.174 & 0.204 \\
Fine sand $(63-200 \mu \mathrm{m})$ & -0.027 & 0.844 \\
\hline
\end{tabular}

Bold in the table highlight significance below 0.05 and their of corresponding pearson correlation.

a Significant correlation at 0.01 level.

b Significant correlation at 0.05 level.

\section{Discussion}

Cyst production occurs due to the occurrence of stressful environmental conditions such as turbulence, a decrease in the seawater temperature, nutrient deficiency or high densities of vegetative cells. This study is the first to simultaneously measure in the sediment levels of major pollutants (trace metals, butylin compounds, PAHs, polar pesticides, PCB) and dinocyst abundance and diversity in order to evaluate if there was any correlations between these contaminants and cyst abundance in recently-deposited sediment of a southern Mediterranean lagoon.

\subsection{Contamination levels within Bizerte lagoon sediments}

Inorganic contaminants within the Bizerte lagoon sediment were mainly represented by trace metals and Tributyltin. The south-western side of the lagoon, represented by stations 8,9 , and 27 , was the most polluted area. The degree of trace metal contamination could be classified into three levels: rarely ( $<$ ERL), occasionally (ERL-ERM) and frequently (>ERM), in terms of its adverse biological effect (Long et al., 1995). Based on the effect-range classification, $\mathrm{As}, \mathrm{Cr}, \mathrm{Pb}, \mathrm{Ni}$ and $\mathrm{Hg}$ were likely to pose environmental risks, with most values for their concentrations exceeding the ERL range. Trace metal levels recorded in this study were mostly similar to those registered in previous studies for most sampling stations (Barhoumi et al., 2014b; Pringault et al., 2015), whereas, the highest concentrations for $\mathrm{Zn}, \mathrm{As}, \mathrm{Pb}$ and $\mathrm{Ni}$ were recorded here for the first time. When comparing results from the current study to those of Yoshida et al. (2002), still conducted for Bizerte lagoon sediment, six trace metals ( $\mathrm{V}, \mathrm{Co}, \mathrm{Al}, \mathrm{Cu}, \mathrm{Cr}$ and $\mathrm{Pb}$ ) presented higher levels and three trace metals ( $\mathrm{Zn}$, As and Mo) presented lower levels than those previously recorded for the same benthic sediments. Compared with other Mediterranean ecosystems, Bizerte lagoon seems to be more polluted than Thau Lagoon (France), Venice lagoon (Italy) and the Turkey coastline, mainly in terms of $\mathrm{Zn}, \mathrm{Pb}, \mathrm{Cr}$ and $\mathrm{Ni}$ (Rigollet et al., 2004; Aydin et al., 2015).

Concerning butylin contamination, the spatial distribution of organotin was homogeneous throughout the lagoon sediments, with moderate levels $\left(0.14-14.91 \mathrm{ngSn} \cdot \mathrm{g}^{-1}\right)$ generally being recorded, except for the two sampling sites 8 and 9 (39.76 and $23.9 \mathrm{ngSn} \cdot \mathrm{g}^{-1}$, respectively), located near the industrial area and the shipyard of Menzel Bourguiba. Butylin levels in the sampled stations within the Bizerte lagoon are lower than those recorded from other comparable Mediterranean coastal systems, such as those in Spain (Barcelona port) $18.7 \mathrm{ngSn} \cdot \mathrm{g}^{-1}$, France (Port-camargue) $10.73 \mathrm{ngSn} \cdot \mathrm{g}^{-1}$ and Venice lagoon $39.3 \mathrm{ngSn} \cdot \mathrm{g}^{-1}$. Whilst the degree of in situ TBT contamination is considered to be moderate, its impact on living organisms could still be considerable (Mzoughi et al., 2005). It has been shown that the Bizerte lagoon exhibited a high rate of imposex within mollusc populations, with an incidence of $28-100 \%$ for Hexaplex trunculus and 77-100\% for Bolinus brandaris. (Lahbib et al., 2012; Abidli et al., 2013). PAHs contamination was mainly localized in the southern part of $\mathrm{Bi}$ zerte lagoon, with the highest concentration recorded being that of $9948.84 \mathrm{ng} \cdot \mathrm{g}^{-1}$. In general, recorded PAHs concentrations ranged from $2.3 \mathrm{ng} \cdot \mathrm{g}^{-1}$ to $49.75 \mathrm{ng} \cdot \mathrm{g}^{-1}$, being lower than those recorded previously in Bizerte lagoon (Trabelsi and Driss, 2005; Barhoumi et al., 2014b). When compared with other Mediterranean ecosystems, PAHs levels were lower than those recorded in the French Thau lagoon (59$76.79 \mathrm{ng} \cdot \mathrm{g}^{-1}$ ) (Leaute, 2008) and in Pialassa Baiona (3.032$87.150 \mathrm{ng} \cdot \mathrm{g}^{-1}$ ) in Italy (Guerra, 2012).

\subsection{Dinocyst abundance and diversity}

This study provides a database on dinocyst assemblage and abundance in the Bizerte lagoon. This could help to detect a potential future introduction of a non-indigenous harmful dinoflagellate species in this ecosystem through human-assisted dispersal. Along the southern Mediterranean shores, few studies were conducted on dinoflagellate cyst

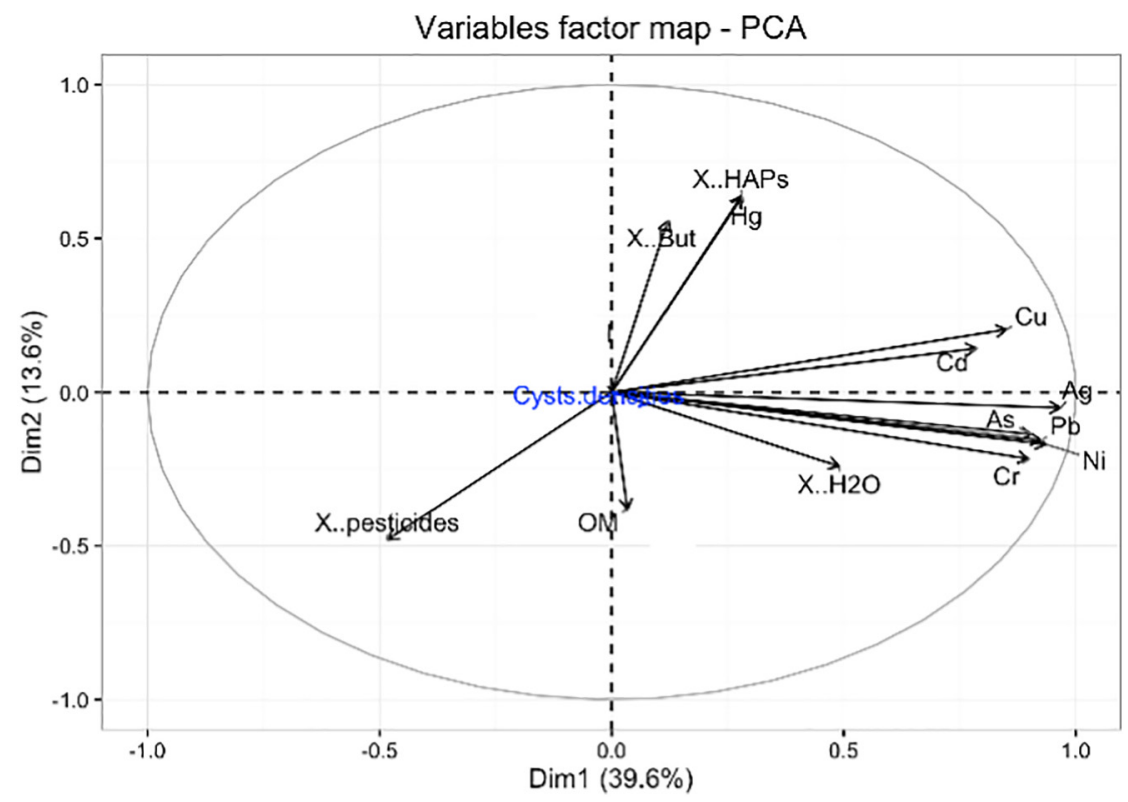

Fig. 9. Principal Component Analyses output results. Total resting cyst densities is included as supplementary factor. 


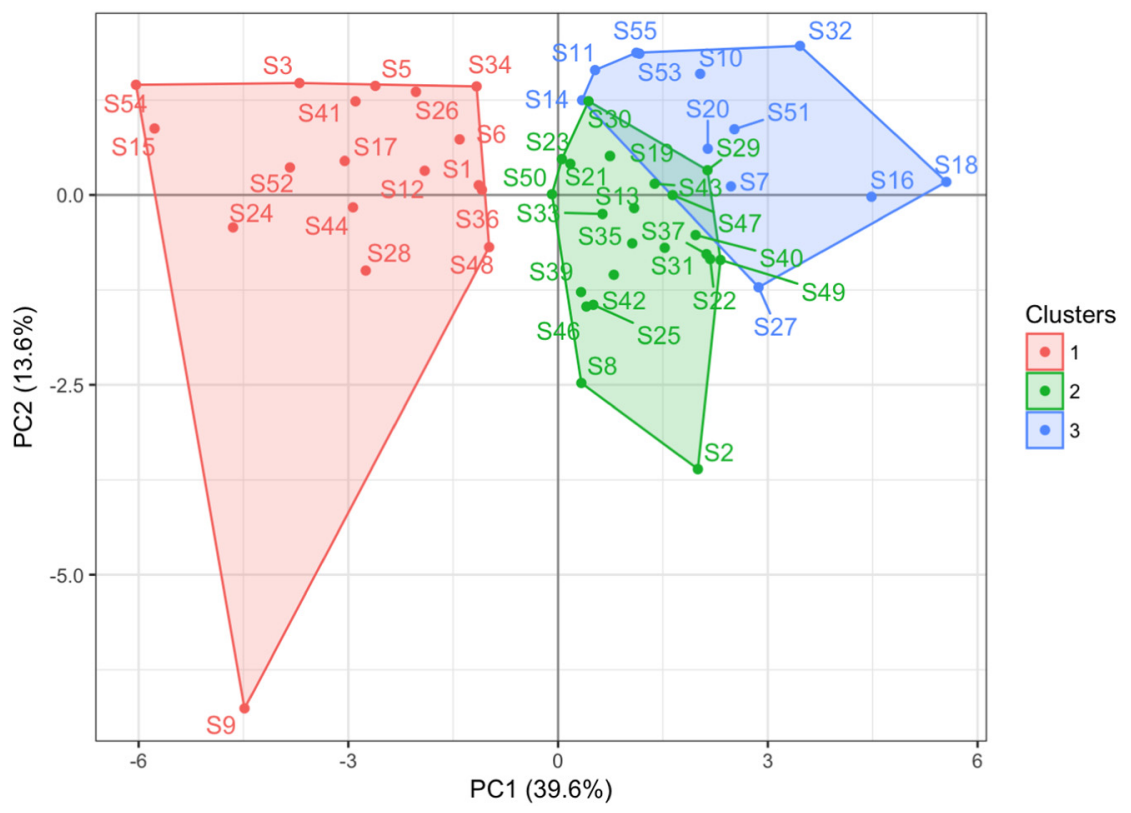

Fig. 10. Principal component analyses output results. Total resting cyst densities is included as supplementary factor.

distribution (Zmerli Triki et al., 2014, 2015b; Fertouna-Bellakhal et al., 2014). We considered Speniferites species as a single speniferites group morphotype so as to avoid potential mis-identification and, in addition, unidentifiable dinoflagellate cysts were not counted. Our data showed that all dinoflagellate cyst morphotypes encountered in the benthic sediment of Bizerte lagoon have been previously recorded in other Mediterranean ecosystems as in Spain and Italy, where they seem to be well-established. Within Bizerte Lagoon benthic sediment, we found high dinoflagellate cyst abundances (203-2742 cysts $\cdot \mathrm{g}^{-1}$ ) as well as moderate cyst diversity (22 cyst morphotypes). Our results concerning dinocyst abundance contrasted with those from other Mediterranean ecosystems which showed a high diversity and a low cyst abundance. As an example, along the Ionian coasts of Sicily (Italy), 34 cyst morphotypes were recorded, with cyst densities ranging from 34 to 828 cysts $\cdot g^{-1}$, whilst in Alfacs and Fangar bays (Spain) 62 cyst morphotypes were recorded, and densities ranging from 21 to 322 cysts $\cdot \mathrm{g}^{-1}$ (Table 3 and references therein). The difference between the cyst morphotype richness values recorded in different studies could be explained in terms of several factors, such as differential dinoflagellate species colonization rates, the thickness of the investigated sediment layer and the inclusion or not of the unidentified morphotypes within the total count of cyst morphotypes and also in terms of the taxonomic identity of species belonging to the speniferites group (the latter is especially an issue when there is a high species richness for this group). In our study, potentially toxic dinoflagellate species represented $30 \%$ of the total morphotypes. A. pseudogonyaulax was the dominant morphotype, reaching a density of $1686 \mathrm{cysts} \cdot \mathrm{g}^{-1} \mathrm{DS}$, followed by Lingulodinium polyedrum and the Alexandrium catenella/tamarense complex with maximum values of 152 and 104 cysts $\cdot g^{-1}$ DS, respectively. Gonyaulax spinifera and Protoceratium reticulatum were the least represented toxic/noxious species in the current study, whereas they are, together with Lingulodinium polyedrum, common in other Mediterranean coastal sediments (Montresor et al., 1998; Giannakourou et al., 2005; Rubino et al., 2010; Satta et al., 2010) and are known to cause toxic blooms, mainly in the northern Adriatic Sea (Honsell et al., 1992).

\subsection{Correlation between the contaminants and dinocyst abundance and distribution}

It's generally assumed that dinocyst distribution and abundance are greatly influenced by the sediment characteristics and the hydrodynamic features of a given area. Our results showed that the sediment in the Bizerte lagoon with the highest silt and water content was characterized by the highest RCs densities and that the hydrodynamics of this marine system influences the cyst dispersal patterns (Zmerli Triki et al., 2014). However, cyst accumulation remains a complex process which cannot be explained exclusively in terms of sediment characteristics and hydrodynamics. Our data suggest that contaminant levels in the sediment could be an additional parameter in explaining the cyst abundance and distribution patterms. In fact, hierarchical clustering on stations performed on RC abundance values and sediment contaminant levels revealed a relationship between the highly polluted stations and the highest RCs abundance. Moreover, the Simultaneous Autoregressive (SAR) model, computed in order to analyze the predictive power of contaminant levels for determining resting cyst abundance, showed that cysts densities in Bizerte lagoon were associated mainly with trace metal concentrations, including those for $\mathrm{Hg}, \mathrm{Cd}, \mathrm{Cu}, \mathrm{Ni}$ and $\mathrm{Cr}$, as well as with sediment water content, suggesting that concentrations for these pollutants could influence RC abundance in the sediment. These results are consistent with previous studies which discussed the effect of contaminants on cyst abundance and distribution. For instance, Horner et al. (2011) investigated the effect of the Cd concentration on Alexandrium catenella cyst distribution and they highlighted a significant positive correlation between the two. Aydin et al. (2015) showed that autotrophic cysts were dominant close to highly contaminated stations in Izmir bay in Turkey. In addition, significant positive correlations between the abundance and distribution of some dinoflagellate species, such as Lingulodinium machaerophorum, Dubridinium caperatum and Polykrikos kofoidii, and the sediment concentration of some metals as $\mathrm{Cd}, \mathrm{Pb}, \mathrm{Cu}$ and $\mathrm{Zn}$ were reported from Izmir bay. Liu et al. (2012) suggested that a high degree of sediment contamination by industrial pollutants might cause a decrease in cyst abundance or heterotrophic/ autotrophic rate.

Within Bizerte lagoon, an anthropized ecosystem, high dinocyst densities were recorded in the surface sediment, whereas no dense blooms related to this phytoplankton group were observed in this ecosystem except for one caused by Alexandrium catenella in 2007. This apparent paradox could be partially explained by: a) the high cyst production rate and the low natural germination rate of the dominant assemblage species (A. pseudogonyaulax), b) the physiological stress induced on the vegetative cells by the remobilized pollutants in the water column could enhance cyst production and c) the inhibition of the 
Table 2

Dinocyst species recorded within the surface sediment of Bizerte lagoon. The potential toxicity of these species as recorded within different Mediterranean case studies is indicated.

\begin{tabular}{|c|c|c|c|c|}
\hline Groups & Dinocyst species & $\begin{array}{l}\text { Abundance } \\
\text { in Bizerte } \\
\text { lagoon }\end{array}$ & Toxine/toxic effect & Presence in the Mediterranean Sea \\
\hline \multirow[t]{9}{*}{ Gonyaulacales } & $\begin{array}{l}\text { Alexandrium pseudogonyaulax } \\
\text { (Biecheler) }\end{array}$ & $* * *$ & $\begin{array}{l}\text { Goniodomine A } \\
\text { (Zmerli Triki et al., } \\
\text { 2016) }\end{array}$ & $\begin{array}{l}\text { Naple, Adriatic sea (Italy), Alfacs Bay (Spain) (Montresor, 1995; Bravo et al., 2006; } \\
\text { Penna et al., 2010; Satta et al., 2013) }\end{array}$ \\
\hline & Alexandrium minutum Halim & $*$ & $\begin{array}{l}\text { Paralytic shellfish } \\
\text { toxins (Bravo et al., } \\
\text { 2006) }\end{array}$ & $\begin{array}{l}\text { Harbour of Alexandria (Egypt), Catalonia, Arenys del mar (Spain); Ionian sea, Adriatic } \\
\text { sea, Tyrrhenian sea, Olbia (Italy), Aegean Sea (Turkey) (Ismael and khadr, 2003; } \\
\text { Anglès et al., 2010; Rubino et al., 2010; Penna et al., 2010; Aydin et al., 2011) }\end{array}$ \\
\hline & $\begin{array}{l}\text { Alexandrium } \\
\text { catenella/tamarense (Whedon } \\
\text { \& Kofoid) Balech }\end{array}$ & ** & $\begin{array}{l}\text { Paralytic shellfish } \\
\text { toxins (Laabir et al., } \\
\text { 2013) }\end{array}$ & $\begin{array}{l}\text { Aegean Sea (Turkey), Ionian Sea, Olbia, (Italy), Thau lagoon (France), Tarragona and } \\
\text { Barcelona Harbours (Spain) (Bravo et al., 2006; Satta et al., 2010; Rubino et al., 2010; } \\
\text { Aydin et al., 2011) }\end{array}$ \\
\hline & $\begin{array}{l}\text { Lingulodinium polyedrum } \\
\text { (Stein) Dodge Lingulodinium sp }\end{array}$ & $* *$ & $\begin{array}{l}\text { Yessotoxin (Paz et } \\
\text { al., 2004) }\end{array}$ & $\begin{array}{l}\text { Ionian Sea, Adriatic sea (Italy), Catalan sea, Arenys del mar, Alfacs and Fangar bays } \\
\text { (Spain) (Rubino et al., 2010; Penna et al., 2010; Satta et al., 2010, 2013) }\end{array}$ \\
\hline & $\begin{array}{l}\text { Gonyaulax cf. spinifera complex } \\
\text { (Claparéde et Lachmann) } \\
\text { Diesing }\end{array}$ & $*$ & $\begin{array}{l}\text { Yessotoxin (Rhodes } \\
\text { et al., 2006) }\end{array}$ & Arenys del mar (Spain), Olbia (Italy) (Satta et al., 2010) \\
\hline & $\begin{array}{l}\text { Protoceratium reticulatum } \\
\text { (Claparède et Lachmann) } \\
\text { Butschli }\end{array}$ & * & $\begin{array}{l}\text { Yessotoxin (Paz et } \\
\text { al., 2004) }\end{array}$ & Adriatic sea (Italy), Alfacs and Fangar bays (Penna et al., 2010; Satta et al., 2013) \\
\hline & $\begin{array}{l}\text { Protoperidinium claudicans } \\
\text { (Paulsen) Balec }\end{array}$ & $* *$ & & $\begin{array}{l}\text { Adriatic sea, Tyrrhenian sea, Olbia and Syracuse bay (Italy) Arenys harbour, Catalonia, } \\
\text { Alfacs and Fangar bays (Spain) (Penna et al., 2010; Garcés et al., 2010; Satta et al., } \\
\text { 2013) }\end{array}$ \\
\hline & Protoperidinium leonis & * & Non toxic & Ionian sea (Rubino et al., 2010) \\
\hline & $\begin{array}{l}\text { Protoperidinium compressum } \\
\text { (Abé) Balech }\end{array}$ & $*$ & Non toxic & $\begin{array}{l}\text { Arenys harbour, Alfacs and Fangar bays (Spain), Adriatic sea, Olbia and Syracuse bay } \\
\text { (Italy) (Garcés et al., 2010; Penna et al., 2010; Satta et al., 2010, 2013) }\end{array}$ \\
\hline \multirow[t]{9}{*}{$\begin{array}{l}\text { Organic } \\
\text { peridiniales }\end{array}$} & $\begin{array}{l}\text { Protoperidinium conicum } \\
\text { (Gran) Balech }\end{array}$ & ** & Non toxic & $\begin{array}{l}\text { Aegean Sea (Turkey), Arenys harbour, Alfacs and Fangar bays (Spain), Olbia, Adriatic } \\
\text { sea, Syracuse bay and Ionian sea (Italy) (Garcés et al., 2010; Satta et al., 2010, 2013; } \\
\text { Rubino et al., 2010; Penna et al., 2010; Aydin et al., 2011) }\end{array}$ \\
\hline & $\begin{array}{l}\text { Protoperidinium oblongum } \\
\text { (Aurivillius) Parke et Dodge }\end{array}$ & ** & Non toxic & $\begin{array}{l}\text { Arenys harbour, Alfacs and Fangar bays (Spain), Olbia and Syracuse bay, Adriatic sea, } \\
\text { Ionian sea (Italy) (Garcés et al., 2010; Penna et al., 2010; Satta et al., 2010, 2013) }\end{array}$ \\
\hline & $\begin{array}{l}\text { Zygabikodinium lenticulatum } \\
\text { (Paulsen) Loeblich }\end{array}$ & $*$ & Non toxic & $\begin{array}{l}\text { Arenys harbour (Spain), Olbia and Syracuse bay (Italy) (Garcés et al., 2010; Satta et al., } \\
2010 \text { ) }\end{array}$ \\
\hline & Diplopsalis lenticular & ** & Non toxic & Ionian Sea (Rubino et al., 2010) \\
\hline & $\begin{array}{l}\text { Scrippsiella cf. precaria } \\
\text { Montresor et Zingone }\end{array}$ & $*$ & Non toxic & $\begin{array}{l}\text { Arenys harbour (Spain), Olbia and Syracuse bay (Italy) (Garcés et al., 2010; Satta et al., } \\
\text { 2010) }\end{array}$ \\
\hline & $\begin{array}{l}\text { Scrippsiella cf. ramonii } \\
\text { Montresor }\end{array}$ & * & Non toxic & Arenys harbour, Alfacs bay (Spain) (Satta et al., 2010) \\
\hline & Scrippsiella trochoidea (Stein) & $* *$ & Non toxic & $\begin{array}{l}\text { Arenys harbour, Alfacs and Fangar bays (Spain), Olbia and Syracuse bay, Ionian Sea, } \\
\text { Catalan sea, Tyrrhenian sea (Italy) (Garcés et al., 2010; Satta et al., 2010; Rubino et al., } \\
\text { 2010) }\end{array}$ \\
\hline & Ensiculifera cf. acminata & * & - & \\
\hline & Scrippsiella rotunda & $*$ & - & \\
\hline \multirow[t]{2}{*}{ Gymnodiniales } & $\begin{array}{l}\text { Polykrikos kofol̈di/schwartzii } \\
\text { complex }\end{array}$ & * & Non toxic & $\begin{array}{l}\text { Aegean Sea (Turkey), Adriatic sea, Olbia (Italy) Alfacs and Fangar bays (Aydin et al., } \\
\text { 2011; Penna et al., 2010) }\end{array}$ \\
\hline & Gymnodinium spp & $*$ & - & \\
\hline Prorocentrales & Prorocentrum micans & $*$ & Toxic & \\
\hline
\end{tabular}

The resting cyst abundance within the sediment of the Bizerte lagoon: $50<{ }^{*}<10^{2}$ cysts $\cdot \mathrm{g}^{-1}$ dry sediment (DS); $10^{2}<{ }^{* *}<10^{3} \mathrm{cysts} \cdot \mathrm{g}^{-1} \mathrm{DS} ;{ }^{* * *}>10^{3}$ cyst $\cdot \mathrm{g}^{-1} \mathrm{dry}$ sediment.

excystement process by the contaminants within the sediment could lead to a considerable cyst accumulation in the sediment.

Liu et al. (2012) showed that toxic compounds in the sediment could induce a decrease of the proliferation of vegetative cells; hence, some cells might die whilst others perform sexual reproduction, resulting in large volumes of resistant cysts enhancing cyst banks. Several laboratory studies have been conducted to date to test the degree of stress posed by metal contamination on vegetative cells. Contaminants affect the physiology of vegetative cells by acting on the levels of oxidative stress in cells (Okamoto and Colepicolo, 1998; Pinto et al., 2003) or by reducing their light-harvesting capacity and by inhibiting cell growth (Miao and Wang, 2006; Herzi et al., 2013). Under high levels of iron, cell

Table 3

Comparison of the number of cyst morphotypes and the total cyst abundance (cysts $\cdot \mathrm{g}^{-1}$ ) in sediment of different coastal ecosystems. NR: not recorded.

\begin{tabular}{|c|c|c|c|c|c|}
\hline Location & Sampling method & $\begin{array}{l}\text { Number of stations } \\
\text { number }\end{array}$ & $\begin{array}{l}\text { Morphotypes } \\
\text { number }\end{array}$ & $\begin{array}{l}\text { Densities } \\
\left(\text { cysts } \cdot \mathrm{g}^{-1} \text { ) }\right.\end{array}$ & References \\
\hline Gulf of Olbia and Arenys del Mar harbour & Cores $(1 \mathrm{~cm})$ & 68 & 42 & $20-5484$ & Satta et al. (2010) \\
\hline Alfacs and Fangar bays & Cores $(1 \mathrm{~cm})$ & 16 & 62 & $21-322$ & Satta et al. (2010) \\
\hline Ionian coasts of Sicily & Cores $(3 \mathrm{~cm})$ & 4 & 34 & $43-828$ & Rubino et al. (2010) \\
\hline Lisbon Bay, Portugal & Manual vacuum pump $(0-2 \mathrm{~cm})$ & 23 & 58 & $212-574$ & Ribeiro and Amorim (2008) \\
\hline Izmir Bay & Corer $(0-2 \mathrm{~cm})$ & 13 & 41 & 3292 & Aydin et al. (2011) \\
\hline Thermaikos Gulf, Aegean Sea, Greece & Corer $(0-10 \mathrm{~cm})$ & & 36 & $385-5718$ & Giannakourou et al. (2005) \\
\hline Sishili Bay, Yellow Sea, China & Core $(0-5 \mathrm{~cm})$ & 22 & 35 & $122-1322$ & Liu et al. (2012) \\
\hline Labrador fjords (canada) & Corer $(5 \mathrm{~mm})$ & 13 & 16 & $1000-6000$ & Richerol et al. (2012) \\
\hline Estuarine south Korea & Corer $(2 \mathrm{~cm})$ & 23 & 47 & $1000-8900$ & Pospelova and Kim (2010) \\
\hline Mexico & Birge Ekman style box sediment sampler & 7 & 17 & NR & Pena-Manjarrez et al. (2005) \\
\hline Eastern coast of Russia & Corer $(2 \mathrm{~cm})$ & 44 & 40 & NR & Orlova et al. (2004) \\
\hline
\end{tabular}


mobility and protein production could be altered, so that vegetative cells can promptly undergo encystment so as to survive the induced high levels of pollutant stress (Lage et al., 1994; Okamoto et al., 1999; Liu et al., 2012). Wang et al. (2001) revealed that the intensity of the effect of pollutants on vegetative cells is largely dependent on the rates of nutrient availability.

It has been shown for instance that organic pollutant such as PAHs (phenanthrene, anthracene, pyrene and fluoranthene) could inhibit the cell growth of some phytoplankton species (Wang et al., 2008; Hong et al., 2008; Echeveste et al., 2010; Ben Othman et al., 2013). Mouhri et al. (1995) showed that the exposure of phytoplankton to TBT induced the intracellular accumulation of nitrogen and phosphorus without their assimilation, resulting in a decrease of the cellular biomass. da Leitao et al. (2003) showed a harmful effect of Arochlor 1254 and $\mathrm{PCB}$ derivative on phytoplankton cells, inducing the oxidative damage of proteins and causing cell growth inhibition.

Laboratory ecotoxicological studies on phytoplankton only assessed the effect of the pollutants on vegetative cells. Until now, no studies have been conducted to test the potential effect of the pollutants on resistant cysts of the dinoflagellate species responsible for the major Harmful Algal Blooms. This consideration should set the agenda for future research on coastal benthic sediments since such laboratory studies could help us better understand the effect of pollutants on the bloom dynamics of HAB-forming species.

\section{Acknowledgements}

This work benefitted from financial supports of the JEAI ECOBIZ (Jeune Equipe Associée, Ecologie de la lagune de Bizerte) program funded in turn by IRD (Institut Français pour la Recherche et le Développement), as well as from the LAGUNOTOX project funded by TOTAL Foundation.

\section{Appendix A. Supplementary data}

Supplementary data to this article can be found online at http://dx. doi.org/10.1016/j.scitotenv.2017.03.183.

\section{References}

Abidli, S., Lahbib, Y., Gonzalez, R.P., Alonso, J.I.G., El Menif, N.T., 2013. Imposex and butyltin burden in Bolinus brandaris (Mollusca, Gastropoda) and sediment from the Tunisian coast. Hydrobiologia 714:13-24. http://dx.doi.org/10.1007/s10750-013-1505-X.

Anderson, D.M., Stock, C.A., Keafer, B.A., Nelson, A.B., Thompson, B., McGillicuddy, D.J., Keller, M., Matrai, P.A., Martin, J., 2005. Alexandrium fundyense cyst dynamics in the Gulf of Maine. Deep-Sea Res. II 52, 2522-2542.

Anderson, D.M., Wall, D., 1978. Potential importance of benthic cysts of Gonyaulax tamarensis and G. excavata in initiating toxic dinoflagellate blooms. J. Phycologia 14 (2), 224-234

Anglès, S., Jordi, A., Garcés, E., Basterretxea, G., Palanques, A., 2010. Alexandrium minutum resting cysts distribution dynamics in a confined site. Deep-Sea Res. II 57, 210-221.

Aydin, H., Erdem Yurur, E., Uzar, S., Kucuksezgin, F., 2015. Impact of industrial pollution on recent dinoflagellate cysts in Izmir Bay (Eastern Aegean). Mar. Pollut. Bull. 94, 144-152.

Aydin, H., Matsuoka, K., Minareci, E., 2011. Distribution of dinoflagellate cysts in recent sediments from Izmir Bay (Aegean Sea, Eastern Mediterranean). Mar. Micropaleontol. 80, 44-52.

Barhoumi, B., LeMenach, K., Devier, M.H., Ben Ameur, W., Etcheber, H., Budzinski, H., Cachot, J., Driss, M.R., 2014b. Polycyclic aromatic hydrocarbons (PAHs) in surface sediments from the Bizerte Lagoon, Tunisia: levels, sources, and toxicological significance. Environ. Monit. Assess. 186, 2653-2669.

Barhoumi, B., LeMenach, K., Devier, M.H., El Megdiche, Y., Hammami, B., Ben Ameur, W. Ben, S., Cachot, J., Budzinski, H., Driss, M.R., 2014a. Distribution and ecological risk of polychlorinated biphenyls (PCBs) and organochlorine pesticides (OCPs) in surface sediments from the Bizerte lagoon, Tunisia. Environ. Sci. Pollut. Res. 21, 6290-6302.

Bejaoui, B., Harzallah, A., Moussa, M., Chapelle, A., Solidoro, C., 2008. Analysis of hydrobiological pattern in the Bizerte lagoon (Tunisia). Estuar. Coast. Shelf Sci. 80, 121-129.

Bellakhal-Fartouna, M., Daly Yahia-Kéfi, O., 2004. Taxonomie et écologie numérique des dinoflagellés au niveau du parc conchylicole de Menzel Jemil (Lagune de Bizerte, Tunisie septentrionale). Rapport de la Commission Internationale pour l'exploration scientifique de la Mer Méditerranée. 37, p. 490.

Belmonte, G., Miglietta, A., Rubino, F., Boero, F., 1997. Morphological convergence of resting stages of planktonic organisms: a review. Hydrobiologia 355, 159-165.
Ben Othman, H., Meddeb, M., Hadj Mabrouk, H., Sakka Hlaili, A., 2013. Effet du benzo(a)pyrene sur la communauté phytoplanctonique du canal et de la lagune de Bizerte. Bull. Inst. Natn. Scien. Tech. Mer de Salammbô. 40, 128-139.

Ben Salem, F., Ben Said, O., Aissa, P., Mahmoudi, E., Monperrus, M., Grunberger, O., Duran, R., 2016. Pesticides in Ichkeul Lake-Bizerta LagoonWatershed in Tunisia: use, occurrence, and effects on bacteria and free-living marine nematodes. Environ. Sci. Pollut. Res. 23 (1), 36-48.

Bolch, C.J.S., 1997. The use of sodium polytungstate for the separation and concentration of living dinoflagellate cysts from marine sediments. Phycologia 36 (6), 472-478.

Bravo, I., Garcés, E., Diogène, J., Fraga, S., Sampedro, N., Figueroa, R.I., 2006. Resting cysts of the toxigenic dinoflagellate genus Alexandrium in recent sediments from the western Mediterranean coast, including the first description of cysts of $A$. kutnerae and A. peruvianum. Eur. J. Phycol. 41 (3), 293-302.

Carlier-Pinasseau, C., Lespes, G., Astruc, M., 1996. Determination of butyltin and phenyltin by GC-FPD following ethylation by NaBEt 4 . Appl. Organomet. Chem. 10 (7), 505-512.

Comete-IHE, 2003. Etude sur la dépollution industrielle dans le bassin versant du lac de Bizerte. Rapport définitif de la phase-1. Direction générale de l'environnement et de la qualité de la vie.

Dale, B., 1983. Dinoflagellate resting cysts: "benthic plankton". In: Fryxell, G.A. (Ed.), Survival Strategies of the Algae. Cambridge University Press, Cambridge, pp. 69-136.

Dale, B., 2001. Marine dinoflagellate cysts as indicators of eutrophication and industrial pollution: a discussion. Sci. Total Environ. 264, 235-240.

Dale, B., 2009. Eutrophication signals in the sedimentary record of dinoflagellate cysts in coastal waters. J. Sea Res. 61, 103-113.

Delgado, M., Fortuno, J.M., 1991. Atlas de Fitoplancton del Mar Mediterraneo. 55. Instituto de Ciencias del Mar. Sci. Mar. (133p).

Drebes, G., 1974. Marine phytoplankton (Diatomeen, Peridinien). Georg Thieme VerlagStuttgart (186p).

Echeveste, P., Agusti, S., Dachs, J., 2010. Cell size dependent toxicity thresholds of polycyclic aromatic hydrocarbons to natural and cultured phytoplankton populations. Environ. Pollut. 158, 299-307.

Elshanawany, R., Zonneveld, K., Ibrahim, M., Kholeif, S.E.A., 2011. Distribution patterns of recent organic-walled dinoflagellate cysts in relation to environmental parameters in the Mediterranean Sea. Palynology 34 (2):233-260. http://dx.doi.org/10.1080/ 01916121003711665.

Fertouna-Bellakhal, M., Dhib, A., Béjaoui, B., Turki, S., Aleya, L., 2014. Driving factors behind the distribution of dinocyst composition and abundance in surface sediments in a western Mediterranean coastal lagoon: report from a high resolution mapping study. Mar. Pollut. Bull. 84, 347-362.

Garcés, E., Satta, C., Anglès, S., Lugliè, A., Rubino, F., Giacobbe, M., Penna, A., 2010. Dinoflagellate cyst assemblages as repertoire of species diversity: main results of the EUSEED project related to Mediterranean sites. Rapport Commission International Mer Méditerranée.

Genovesi, B., Laabir, M., Masseret, E., Collos, Y., Vaquer, A., Grzebyk, D., 2009. Dormancy and germination features in resting cysts of species complex (Dinophyceae) can facilitate bloom formation in a shallow lagoon (Thau, southern France). J. Plankton Res. 31 (10), 1209-1224.

Giannakourou, A., Orlova, T.Y., Assimakopoulou, G., Pagou, K., 2005. Dinoflagellate cysts in recent marine sediments from Thermaikos Gulf, Greece: effects of resuspension events on vertical cyst distribution. Cont. Shelf Res. 25, 2585-2596.

Godhe, A., McQuoid, M.R., 2003. Influence of benthic and pelagic environmental factors on the distribution of dinoflagellate cysts in surface sediments along the Swedish West coast. Aquat. Microb. Ecol. 32, 185-201.

Guerra, R., 2012. Polycyclic aromatic hydrocarbons, polychlorinated biphenyls and trace metals in sediments from a coastal lagoon (Northern Adriatic, Italy). Water Air Soil Pollut. 223, 85-98.

Harrison, P.J., Waters, R., Taylor, F.J.R., 1980. A broad spectrum artificial seawater medium for coastal and open ocean phytoplankton. J. Phycol. 16, 28-35.

Herzi, F., Jean, N., Zhao, H., Mounier, S., Hadj Mabrouk, H., Sakka Hlaili, A., 2013. Copper and cadmium effects on growth and extracellular exudation of the marine toxic dinoflagellate Alexandrium catenella: 3D-fluorescence spectroscopy approach. Chemosphere 93, 1230-1239.

Hong, Y.W., Yuan, D.X., Lin, Q.M., Yang, T.L., 2008. Accumulation and biodegradation of phenanthrene and fluoranthene by the algae enriched from a mangrove aquatic ecosystem. Mar. Pollut. Bull. 56, 1400-1405.

Honsell, G., Boni, L., Cabrini, M., Pompei, M., 1992. Toxic or potentially toxic dinoflagellates from the Northern Adriatic Sea. Sci. Total Environ. 107-113.

Horner, R.A., Greengrove, C.L., Davies-Vollum, K.S., Gawel, J.E., Postel, J.R., Cox, A.M., 2011. Spatial distribution of benthic cysts of Alexandrium catenella in surface sediments of Puget Sound, Washington, USA. Harmful Algae 11, 96-105.

Ismael, A.A., Khadr, A.M., 2003. Alexandrium minutum cysts in sediment cores from the eastern harbour of Alexandria, Egypt. Oceanologia. 45, 721-731.

Laabir, M., Collos, Y., Masseret, E., Grzebyk, D., Abadie, E., Savar, V., Sibat, M., Amzil, Z., 2013. Influence of environmental factors on the paralytic shellfish toxin content and profile of Alexandrium catenella (Dinophyceae) isolated from the Mediterranean Sea. Mar. Drugs 11 (5), 1583-1601.

Lage, O.M., Parente, A.M. Soares, H.M.V.M., Vasconselos, M.T.S.D., Salema, R. 1994. Some effects of copper on the dinoflagellates Amphidinium carterae and Prorocentrum micans in batch culture. Eur. J. Phycol. 29, 253-260.

Lahbib, Y., Abidli, S., El Menif, N.T., 2012. TBT pollution in Tunisian coastal lagoons as indicated by imposex in Hexaplex trunculus (Gastropoda: Muricidae). Transit. Water. Bull. 6, 34-41.

Leaute, F., 2008. Biogéochimie des contaminants organiques HAP, PCB et Pesticides organochlorés dans les sédiments de l'étang de Thau (France). Thèse de Doctorat. Université de Pierre et, Marie Curie, France. 
da Leitao, M.A.S., Cardozo, K.H.M., Pinto, E., Colepicolo, P., 2003. PCB-induce oxidative stress in the unicellular marine dinoflagellate Lingulodunium polyedrum. Arch. Environ. Contam. Toxicol. 45:59-69. http://dx.doi.org/10.1007/s00244-002-0208-5.

Liu, D., Shi, Y., Di, B., Sun, Q., Wang, Y., Dong, Z., Shao, H., 2012. The impact of different pollution sources on modern dinoflagellate cysts in Sishili Bay, Yellow Sea, China. Mar. Micropaleontol. 84, 1-13.

Long, E.R., MacDonald, D.D., Smith, S.L., Calder, F.D., 1995. Incidence of adverse biological effects within ranges of chemical concentrations in marine and estuarine sediments. Environ. Manag. 19 (1), 81-97.

Mansouri, T., 1996. Application de la télédétection et des systèmes d'information géographiques à l'étude du fonctionnement hydrologique du lac de Bizerte et son bassin versant. Mémoire de D.E.A. Géologie appliquée à l'environnement. Faculté de Science de Tunis (101p).

Matsuoka, K., 1999. Eutrophication process recorded in dinoflagellate cyst assemblages a case of Yokohama Port, Tokyo Bay, Japan. Sci. Total Environ. 231, 17-35.

Matsuoka, K., Fukuyo, Y., 2000. Technical Guide for Modern Dinoflagellates Cyst Study. WESTPAC-HAB Asian Natural Environmental Science Center, Tokyo.

Miao, A., Wang, W., 2006. Cadmium toxicity to two marine phytoplankton under different nutrient condition. Aquat. Toxicol. 78, 114-126.

Montresor, M., 1995. The life history of Alexandrium pseudogonyaulax (Gonyaulacales, Dinophyceae). Phycologia 34, 444-448.

Montresor, M., Zingone, A., Sarno, D., 1998. Dinoflagellate cyst production at a coastal Mediterranean site. J. Plankton Res. 20 (12), 2291-2312.

Mosulén, S., Dominguez, M.J., Vigara, J., Vilchez, C., Guiraum, A., Vega, J.M., 2003. Metal toxicity in Chlamydomonas reinhardtii. Effect on sulfate and nitrate assimilation. Biomol. Eng. 20, 199-203.

Mouhri, K., Marsot, P., Pelletier, E., Loudik, M., Saint-louis, R., 1995. Effets du chlorure de tributylétain sur la croissance et le métabolisme de la diatomée marine Phaeodactylum tricornutum (Bohlin). Oceanol. Acta 18, 3.

Mzoughi, N., Lespes, G., Bravo, M., Dachraoui, M., Potin-Gautier, M., 2005. Organotin speciation in Bizerte lagoon (Tunisia). Sci. Total Environ. 349, 211-222.

Okamoto, O.K., Colepicolo, P., 1998. Response of superoxide dismutase to pollutant metal stress in the marine dinoflagellate Gonyaulax polyedra. Comp. Biochem. Physiol. C 119, 67-73.

Okamoto, O.K., Shao, L., Hastings, J.W., Colepicolo, P., 1999. Acute and chronic effects of toxic metals on viability, encystment and bioluminescence in the dinoflagellate Gonyaulax polyedra. Comp. Biochem. Physiol. C 123, 75-83.

Orlova, T.Y., Morozova, T.V., Gribble, K.E., Kulis, D.M., Anderson, D.M., 2004. Dinoflagellate cysts in recent marine sediments from the east coast of Russia. Bot. Mar. 47, 184-201.

Paz, B., Riobo', P., Fernandez, M.L., Fraga, S., Franco, J.M., 2004. Production and release of yessotoxins by the dinoflagellates Protoceratium reticulatum and Lingulodinium polyedrum in culture. Toxicon $44,251-258$.

Pena-Manjarrez, J.L., Helenes, J., Gaxiola-Castro, G., Orellano Cepeda, E., 2005. Dinoflagellate cysts and bloom events at Todos Santos Bay, Baja California, México, 1999-2000. Cont. Shelf Res. 25, 1375-1393.

Penna, A., Battocchi, C., Garcés, E., Anglès, S., Cucchiari, E., Totti, C., Kremp, A., Satta, C., Giacobbe, M.G., Bravo, I., Bastianini, M., 2010. Detection of microalgal resting cysts in European coastal sediments using a PCR-based assay. Deep-Sea Res. II 57 (3-4), 288-300.

Pielou, E.C., 1966. The measurement of diversity in different types of biological collections. J. Theor. Biol. 13, 131-144.

Pinto, E., Sigaud-Kutner, T.C.S., Leitao, M.A.S., Okamoto, O.K., Morse, D., Colepicolo, P., 2003. Heavy metal-induced oxidative stress in algae. J. Phycol. 39, 1008-1018.

Pospelova, V., Chmura, G.L., Boothman, W.S., Latimer, J.S., 2005. Spatial distribution of modern dinoflagellate cysts in polluted estuarine sediments from Buzzards Bay (Massachusetts, USA) embayments. Mar. Ecol. Prog. Ser. 292, 23-40.

Pospelova, V., Kim, S.J., 2010. Dinoflagellate cysts in recent estuarine sediments from aquaculture sites of southern South Korea. Mar. Micropaleontol. 76, 37-51.

Pringault, O., Aube, J., Bouchez, O., Klopp, C., Mariette, J., Escudie, F., Senin, P., Goni-Urriza, M., 2015. Contrasted effects of natural complex mixtures of PAHs and metals on oxygen cycle in a microbial mat. Chemosphere 135, 189-201.

Rai, L.C., Tyagi, B., Rai, P.K., Mallick, N., 1998. Interactive effects of UV-B and heavy metals ( $\mathrm{Cu}$ and $\mathrm{Pb}$ ) on nitrogen and phosphorus metabolism of a $\mathrm{N}_{2}$-fixing cyanobacterium Anabaena doliolum. Environ. Exp. Bot. 39, 221-231.

Rhodes, L., McNabb, P., De Salas, M., Briggs, L., Beuzenberg, V., Gladstone, M., 2006. Yessotoxin production by Gonyaulax spinifera. Harmful Algae 5, 148-155.
Ribeiro, S., Amorim, A., 2008. Environmental drivers of temporal succession in recent dinoflagellate cyst assemblages from a coastal site in the North-East Atlantic (Lisbon Bay, Portugal). Mar. Micropaleontol. 68, 156-178.

Richerol, T., Pienitz, R., Rochon, A., 2012. Modern dinoflagellate cyst assemblages in surface sediments of Nunatsiavut fjords (Labrador, Canada). Mar. Micropaleontol. 8889, 54-65.

Rigollet, V., Sfriso, A., Marcomini, A., De Casabianca, M.L., 2004. Seasonal evolution of heavy metal concentrations in the surface sediments of two Mediterranean Zoster marina L. beds at Thau lagoon (France) and Venice lagoon (Italy). Bioresour. Technol. 95 (2):159-167. http://dx.doi.org/10.1016/j.biortech.2003.12.018.

Rossi, N., Jamet, J.L., 2008. In situ heavy metals (copper, lead and cadmium) in different plankton compartments and suspended particulate matter in two coupled Mediterranean coastal ecosystems (Toulon Bay, France). Mar. Pollut. Bull. 56, 1862-1870.

Rubino, F., Belmonte, M., Caroppo, C., Giacobbe, M., 2010. Dinoflagellate cysts from surface sediments of Syracuse Bay (Western Ionian Sea, Mediterranean). Deep-Sea Res. II 57, 243-247.

Satta, C., Anglès, S., Garcés, E., Luglie, A., Padedda, B., Sechi, N., 2010. Dinoflagellate cysts in recent sediments from two semi-enclosed areas of the western Mediterranean Sea subject to high human impact. Deep-Sea Res. II 57 (34), 256-267.

Satta, C.T., Anglès, S., Luglie, A., Guillén, J., Sechi, N., Camp, J., Garcés, E., 2013. Studies on dinoflagellate cyst assemblages in two estuarine Mediterranean bays: a useful too for the discovery and mapping of harmful algal species. Harmful Algae 24, 65-79.

Shannon, C.E., Weaver, W., 1949. The Mathematical Theory of Communication. University of Illinois Press, Urbana, IL.

Steidinger, K., Garcès, E., 2006. Life cycles of harmful algae: An overview. In: Graneli, E., Turner, J.T. (Eds.), Ecology of Harmful Algae. Springer Verlag, pp. 37-49.

Steidinger, K.A., Tangen, K., 1996. Dinoflagellates. In: Tomas, C.R., Hasle, G.R., Steidinger, K.A., Syvertsen, E.E., Tangen, K. (Eds.), Identifying Marine Diatoms and Dinoflagellates. Academic Press, Inc. Harcourt Brace and Company, pp. 387-598.

Thorsen, T.A., Dale, B., 1997. Dinoflagellate cysts as indicators of pollution and past climate in a Norwegian fjord. The Holocene 7, 433-446.

Trabelsi, S., Driss, M.R., 2005. Polycyclic aromatic hydrocarbons in superficial coastal sediments from Bizerte Lagoon, Tunisia. Mar. Pollut. Bull. 50, 344-359.

Turki, S., Balti, N., Ben Jannet, H., 2007. First bloom of dinoflagellate Alexandrium catenella in Bizerte Lagoon (northern Tunisia). Harmful Algae News 35.

Wang, W.X., Dei, R.C.H., Hong, H., 2005. Seasonal study on the Cd, Se, and Zn uptake by natural coastal phytoplankton assemblages. Environ. Toxicol. Chem. 24, 161-169.

Wang, W.X., Dei, R.C.H., Xu, Y., 2001. Responses of Zn assimilation by coastal plankton to macronutrients. Limnol. Oceanogr. 46 (6), 1524-1534.

Wang, L., Zheng, B., Meng, W., 2008. Photo induced toxicity of four polycyclic aromatic hydrocarbons, singly and in combination, to the marine diatom Phaeodactylum tricornitum. Ecotoxicol. Environ. Saf. 71, 465-472.

White, A.W., Lewis, C.M., 1982. Resting cysts of the toxic, red tide dinoflagellate Gonyaulax excavata in Bay of Fundy sediments. Can. J. Fish. Aquat. Sci. 39, 1185-1194.

Yoshida, M., Hamdi, H., Abdul Nasser, I., Jedidi, N., 2002. Contamination of Potentially Toxic Elements (PTEs) in Bizerte lagoon bottom sediments, surface sediment and sediment repository. RPP-SEPMCL Initial Report. 2002.

Zmerli Triki, H., Ben Amor, O., Deidun, A., Kéfi-Daly Yahia, O., 2015b. Investigating the possible influence of different environmental factors on the Alexandrium catenella/ tamarense resting cyst distribution and HAB occurrence within Bizerte lagoon (Mediterranean coast of Tunisia). Mar. Life 18, 43-53.

Zmerli Triki, H., Kefi Daly-Yahia, O., Malouche, D., Komiha, Y., Deidun, A., Brahim, M. Laabir, M., 2014. Resting cysts distribution of the potentially toxic dinoflagellate Alexandrium pseudogonyaulax in recent sediment of Bizerte Lagoon (Mediterranean coast, Tunisia). Mar. Pollut. Bull. 84, 172-181.

Zmerli Triki, H., Laabir, M., Kéfi-Daly Yahia, O., 2015a. Life history, excystment characterics and growth rate of the southern mediterranean harmful dinoflagellate Alexandrium pseudogonyaulax grown at different environmental conditions. J. Phycol. 51 (5): 980-989. http://dx.doi.org/10.1111/jpy.12337.

Zmerli Triki, H., Laabir, M., Moeller, P., Chomérat, N., Kéfi Daly-Yahia, O., 2016. First report of goniodomin A production by the dinoflagellate Alexandrium pseudogonyaulax developing in southern Mediterranean (Bizerte Lagoon, Tunisia). Toxicon 111, 91-99. 